\title{
ELKO $1^{\circ} \times 2^{\circ}$ NTMS AREA NEVADA AND UTAH
}

\section{MASTER}

\section{DATA REPORT}

NATIONAL URANIUM RESOURCE EVALUATION PROGRAM

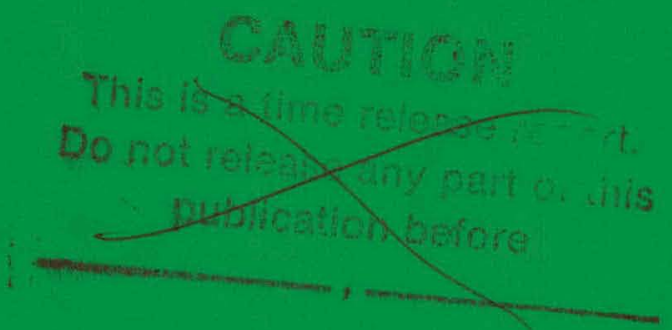

HYDROGEOCHEMICAL AND STREAM

SEDIMENT RECONNAISSANCE

W. M. FAY
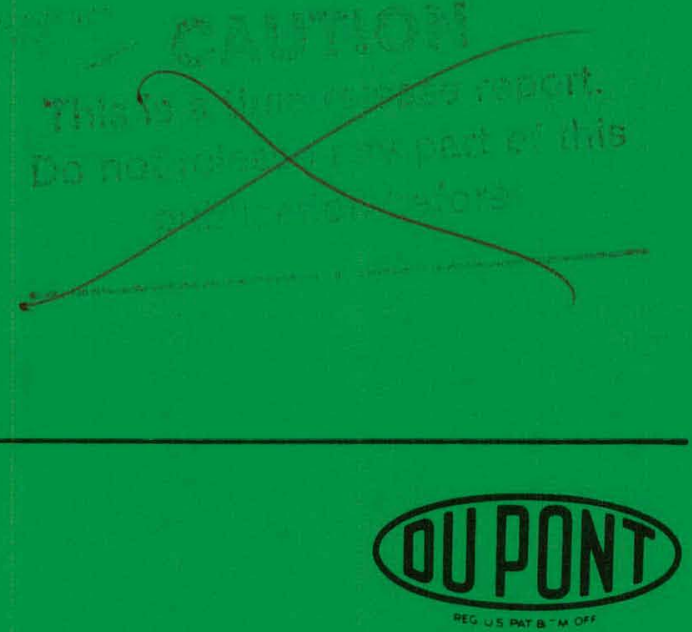

E. I. du Pont de Nemours \& Co. Savannah River Laboratory Aiken, SC 29808 


\section{DISCLAIMER}

This report was prepared as an account of work sponsored by an agency of the United States Government. Neither the United States Government nor any agency Thereof, nor any of their employees, makes any warranty, express or implied, or assumes any legal liability or responsibility for the accuracy, completeness, or usefulness of any information, apparatus, product, or process disclosed, or represents that its use would not infringe privately owned rights. Reference herein to any specific commercial product, process, or service by trade name, trademark, manufacturer, or otherwise does not necessarily constitute or imply its endorsement, recommendation, or favoring by the United States Government or any agency thereof. The views and opinions of authors expressed herein do not necessarily state or reflect those of the United States Government or any agency thereof. 


\section{DISCLAIMER}

Portions of this document may be illegible in electronic image products. Images are produced from the best available original document. 
This report was prepared as an account of work sponsored by the Unitec States Government. Neither the United States nor the United States Jepartment of Energy. nor any of their employees, make any warranty, ex press or implied, or assumes any legal liability or responsibility for the accuracy, completeness, or usefulness of any information, apparatus, product, or process disciosed, or represents that its use would not infringe privately awned rights. Reference herein to any specific commercial product, rocess, or service by trade name, mark, manufacturer, or other wise, does rot necessarily constitute or imply its endorsement, recommendation. or favaring by the United States Government or any agency thereof. The views and opinions of authors expressed herein do not necessarily state or reflect those of the United States Government or any agency theraof.

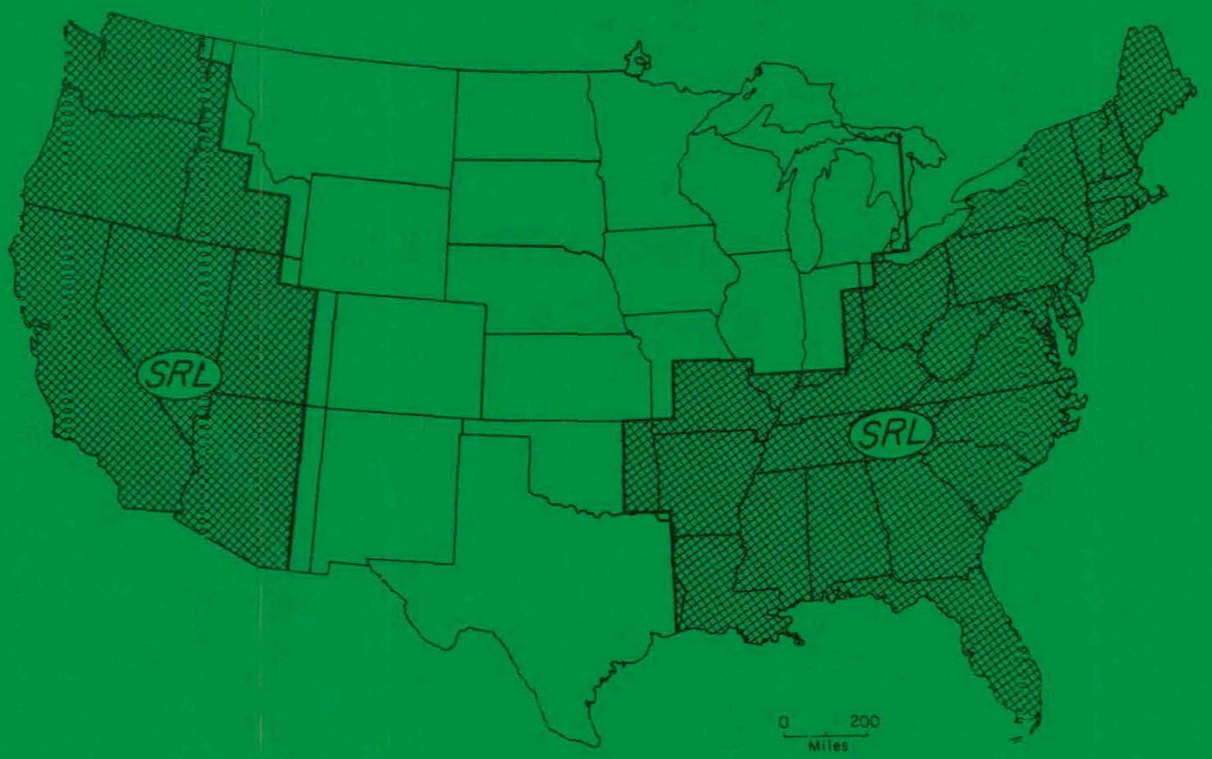




\section{ELKO $1^{\circ} \times 2^{\circ}$ NTMS AREA NEVADA AND UTAH}

\section{DATA REPORT}

\author{
NATIONAL URANIUM RESOURCE \\ EVALUATION PROGRAM
}

\section{HYDROGEOCHEMICAL AND STREAM SEDIMENT RECONNAISSANCE}

W. M. FAY

Approved by

M. L. Hyder, Research Manager Analytical Chemistry Division

Publication Date: July 1980

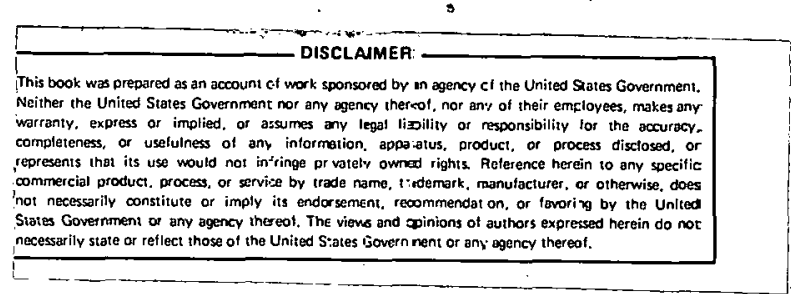

\section{E. I. du Pont de Nemours B. Co. Savannah River Laboratory Aiken, SC 29808}


This data report presents results of ground water and surface sadiment reconneissance in the National Topographic Map Series (NTMS) E $\mathrm{E}^{\circ} 1^{\circ} \times 2^{\circ}$ quadrangle. The target sampling density was one site per 12 square kilometers. This resulted in 1713 sediment samples being ccillected; however, dry conditions and sparse population contributed to the relative 1 y small number of ground water (154. samples) collected. Neutron activation analysis (NAA) results aze given for uranium and 16 other elements in sediments, and for uzanium and 9 other elements in ground water. Mass spectrometry results are given for helium in ground water. Field measurements and observations are reported for each site. Analytical data and field measurements are presented in tables and maps. Statistical summaries of data and a brief description of results are given. A generalized geologic map and a summary of the geology of the area are included.

Late from ground wate= sites (on microfiche in pocket) include (i) water chemistry measurements ( $\mathrm{pH}$, conductivity, and alkalinity), (2) physical measurements where applicable (water temperature, well description, and scintillometer reading), and (3) elenental analyses (U, $\mathrm{Al}, \mathrm{Br}, \mathrm{Cl}, \mathrm{Dy}, \mathrm{F}, \mathrm{He}, \mathrm{Mg}, \mathrm{Mn}, \mathrm{Na}$, and $\mathrm{V}$ ).

Data from sediment sites (also on microfiche in pocket) include (1) strean water chemistry measurements (where available) for $\mathrm{pH}$, conductivity, and alkalinity, and (2) elemental analyses ( $U$, $T h$, $\mathrm{Hf}, \mathrm{Al}, \mathrm{Ce}, \mathrm{Dy}, \mathrm{Eu}, \mathrm{Fe}, \mathrm{La}, \mathrm{Iu}, \mathrm{Mn}, \mathrm{Sc}, \mathrm{Sm}, \mathrm{Na}, \mathrm{Ti}, \mathrm{V}$, and $\mathrm{Yb}$ ). Semple site descriptors (coordinates, vegetation, etc.) are also tabulated. Areal distribution maps, histograms, and cumulative frequency plots for most elements, $U / T h$ and $U / H f$ ratios, and scintillometer readings for sediment samples are included on the microfiche. 
Introduction 7

Geologic Sumnary and Mineral Occurrences 10

Hydrology 23

Factors Affecting the Data 27

Quality Assurance 27

Description of Data Tables 27

Results and Discussion of the Data 35

Acknowledgments $\quad 40$

References $\quad 41$ 
1 Location Map for the Elko $1^{\circ} \times 2^{\circ}$ NTMS Quadrangle 9

2 Lozation of the Elkc Quadrangle on a Physiographic Pravince Kap il

3 SRL Field Data Form for Western Quadrangles 28

\section{LIST OE' TABLES}

1 Summary of Tertiary Igneous Events in the E1ko Quadrangle 14

2 Radiometric Ages of Racks in the Elko $1^{\circ} \times 2^{\circ}$ NTrS Quadrangle: 15

3 Precipitation Tatals for 1979 at Selected Weather Stations in the Elko Quadrangle 24

4 Accuracy end Precision of Analyses of SRL Sediment Standards 29

5 Statistical Summary Jf Elemental

Analyses - Sediment; E1ko 36

6 Statistical Summary of Field Measurements and Elemental Analyses - Ground Water; Elko 39 
PLATE 1A Gealogic Map of the Elko Quadrangle

PLATE 1B Mineral Resources in the Elko Quadrangle

PLATE 2. Ground Water Sample Site Locations in the Elko Quadrangle

PLATE 3 Sediment Sample Site Locations in the Elko Quadrangle

PLATE 4 Uranium Distribution in Surface Sediments of the Elko Quadrangle

PLATE 5 Thcrium Distribution in Surface Sediments of the Elko Quadrangle

PLATE 6 Uranium Distribution in Ground Waters of the Elko Quadrangle

PLATE 7 Conductivity Distribution in Ground Waters of the Elko Quadrangle 


\section{ELRO TABLES}

Tabulated reconneissance data and elemental ccncentrations in surface sediment samples and ground water samples itables A and $B$ ).

\section{ELKO PLOTS}

Areal distribut:on maps, histograms, and cumularive frequency plots for elenental E, Th, Hf, La, Ce, Sm, Eu, Dy, Yb, Lu, $\mathrm{Al}, \mathrm{V}, \mathrm{Ti}, \mathrm{Mn}, \mathrm{Fe}, \mathrm{Sc}, \mathrm{Na}$; U/Th and U/Hf ratios; and scinillometer readings for sediments.

\section{ELRO GROUND-WATER PLOTS}

Areal distribu:ion maps, histograms, and frequency distribution plots for $\mathrm{J}, \mathrm{F}, \mathrm{Na}, \mathrm{Mg}, \mathrm{Al}, \mathrm{Cl}, \mathrm{Mn}, \mathrm{Br}, \mathrm{Dy}, \mathrm{V}$, conductivity, alkalinity: $\mathrm{pH}, \mathrm{U} \times 1000 /$ conductivity, $\mathrm{He}$, and scintillometer raadings for ground water samples.

\section{USER'S GUIDE}




\section{INTRODUCTION}

The National Uranium Resource Evaluation (NURE) program was established to evaluate domestic uranium resources in the continental United States and to identify areas favorable for uranium exploration. The Grand Junction Office (GJO) of the Department of Energy (DOE) is responsible for administering and coordinating NURE program efforts. The Savannah River Laboratory (SRL) has responsibility for hydrogeochemical and stream/surface sedinent reconnaissance (HSSR) of 3.9 million square kilometers $(1,500,000$ square miles) in 37 eastern and western states. Other DOE iaboratories are responsible for similar reconnaissance in the rest of the continental United States, including Alaska. The signi icance of the distribution of uranium in natural waters and sediments will be assessed as an indicator of areas favorable for the location of uranium deposits.

The principal objectives of the NURE program are:

- Increase geologic knowledge of U.S. uranium resources in regions where uranium ore bodies are known to exist and are candidate supplies under present and near-term market conditions.

- Complete assessment of lower cost potential uranium resources in the conterminous U.S. and Alaska.

- Improve reliability and validate resource estimates and increase confidence levels.

- Expand scope of uranium assessment to include higher cost and relatively unknown domestic resources that may be feasible uranium supply alternatives.

- Apply advanced technologies for detection and assessment of uranium resources.

DOE-GJO is responsible for administering and coordinating efforts to meet these objectives, including distribution of reports. Inputs to the NURE program come from DOE prime 
contractors, JOE-sponsored research and development, the uranium industry, U.S. Geologic Survey, U.S. Bureau of Mines, other federal and state government agencies, and independent sources.

The NURF program consists of six parts:

1. Hydrogeociemical anc Stream Sediment Reconnaissance Survey

2. Aerial Ratiometzic Survey

3. Intermediate Grade Resource Stucies

4. World Class Geologic Studies

5. Subsurface Geologic Investigation

6. Technolog: Application

The data presented here are reconnaissance data intended for use in identifying broad areas for further study. Thile care has been taken to provide reliable sampling and analyses, verification of individual analyses is beyond the scope of this report. The data stould be viewed statistically because "one-point anomalies" may be misleading. Regional trends, however, shou-d be reliable. With careful consideration of regior.al geology, these data should provide reliajle guides to areas warranting further study.

This report is one of a series presenting basic data obtained by SRL reconnaissance. In the interest of disseminating available data as soon. $3 s$ possible, only neutron activation analyses are reported here. Supp ementary reports will be issued later. All data will be availabie on magnetic tape from:

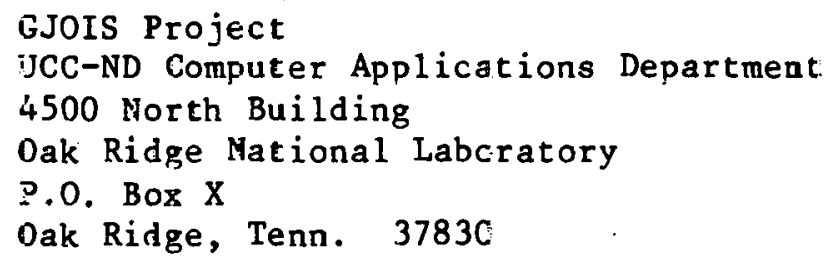

A brief description of sampling and analytical procedures and a detailed description of the maps, tables, and figures contained in this repor: are presented in the SRL document OSER'S GOIDE included on microfiche in the pocket on the inside tack cover of this r $\equiv$ port. A summary of the SRL cevelopment program in support of the reconnaissance is available in SRL-NURE progress reports (SRL-138). SRL data reforts (SRL-146) have been open-filed for other sestern quadrangles (Figure 1). 


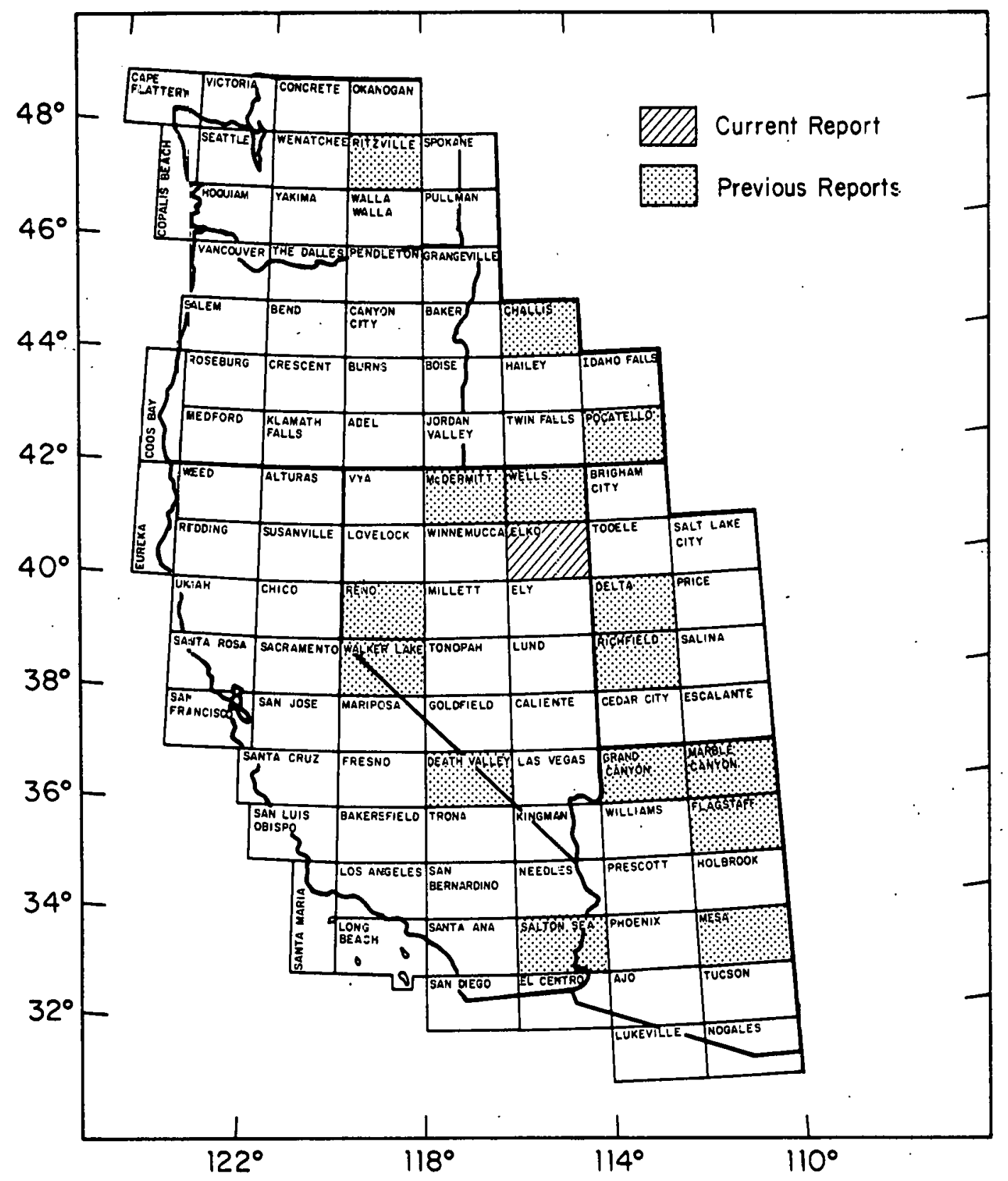

FIGURE 1. Location Map for the Elko $1^{\circ} \times 2^{\circ}$ HTMS Quadrangle 


\section{GEOLOGIC SUMMART AND MINEEAL OCCURRENCES}

\section{General Features}

The Elko $1^{\circ} \times 2^{\circ}$ NTMS quadrangle lies in the Basiz and Range Province, known also as the Great Basin (Figure 2). Tie Great Easin is characterized by isolated, nearly parallel, Irountain ranges (commonly fault blocks) and intervening plains filled with detrital material. The area has been orogenically antive from at least Precambrian time (Nolan, 1943). The area experienced a series of geosynclines and orogenic interruptions thrcughout the Paleozoiz and rost of the Masozoic Eras, culminating in the orogeny which formed tine present Great Basin and whi=t is continuing at fresent (Rojerts and others, 1967).

The rocks of the Pal ments formed ir. a geasynclinal sea. Paleozoic orogenies include the Crdovician Ruby disturbance, the Devonian Ant ler crogeny, and the Fermian Soroma arageny. Jplift of the area became general in the Mesozoic Era with only localized sedimentation. l-plift was culminated in the Tertiary Period with a series of vollcanic eruptions related to block faulting.

\section{Structural History}

Precambrian rocks of the Elko $1^{\circ} \times 2^{\circ}$ NTMS quacrangle are represented by the McCoy Creek Group (Misch and Hazzard, 1962) and by unnamed Precambrian metamorphic rocks of the Ruby Mountains and East Humboldt Range. Precambrian orogenic cycles are not clearly defined, but at least one orogeny (Misch, 1960) and possibly three orogenies (Misch and Hazzard, 1962) raqe affected Precambrian rocks of the Great Basin.

The Paleozoic Era was host to at least three orogenic episodes (Erickson and Marst, 1974); the Ruby disturbance which is an Ordovician tectonism (Willden and Kistler, 1967); the Late Devonian to Early Pennsylvanian Ant ler Orogeny (Roberis and others, 1958; Roberts; 1964a; 1964b; 1966), and the Late Permian Sonoma orogeny (Silberling and Roberts, 1962). The Somoma orogeny may be reflected in this quadrangle by Latest Permiar. deformation of Permian rocks in the Diamond Range (Brew, 1961b; Iarson and Riva, 1963; Brew, 1953). The earliest Paleozoic tectsnic episode, the Ruby disturbance, occuzred between Early Ordovician and Silurian times. (Willden and Kistler, 1967) and is displayed in the Cambrian and Lower Drdovician rocks of the southern Euby Mountains. These rocks ar $z$ folded and show affects of regional metamorohism. The Lower Paleozoic rocks are unconfurnably overlain by Devonian rocks with a different structural regime. In areas outside the southern Ruby Mountains, this tectonic episode

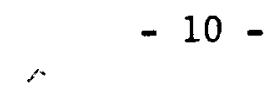



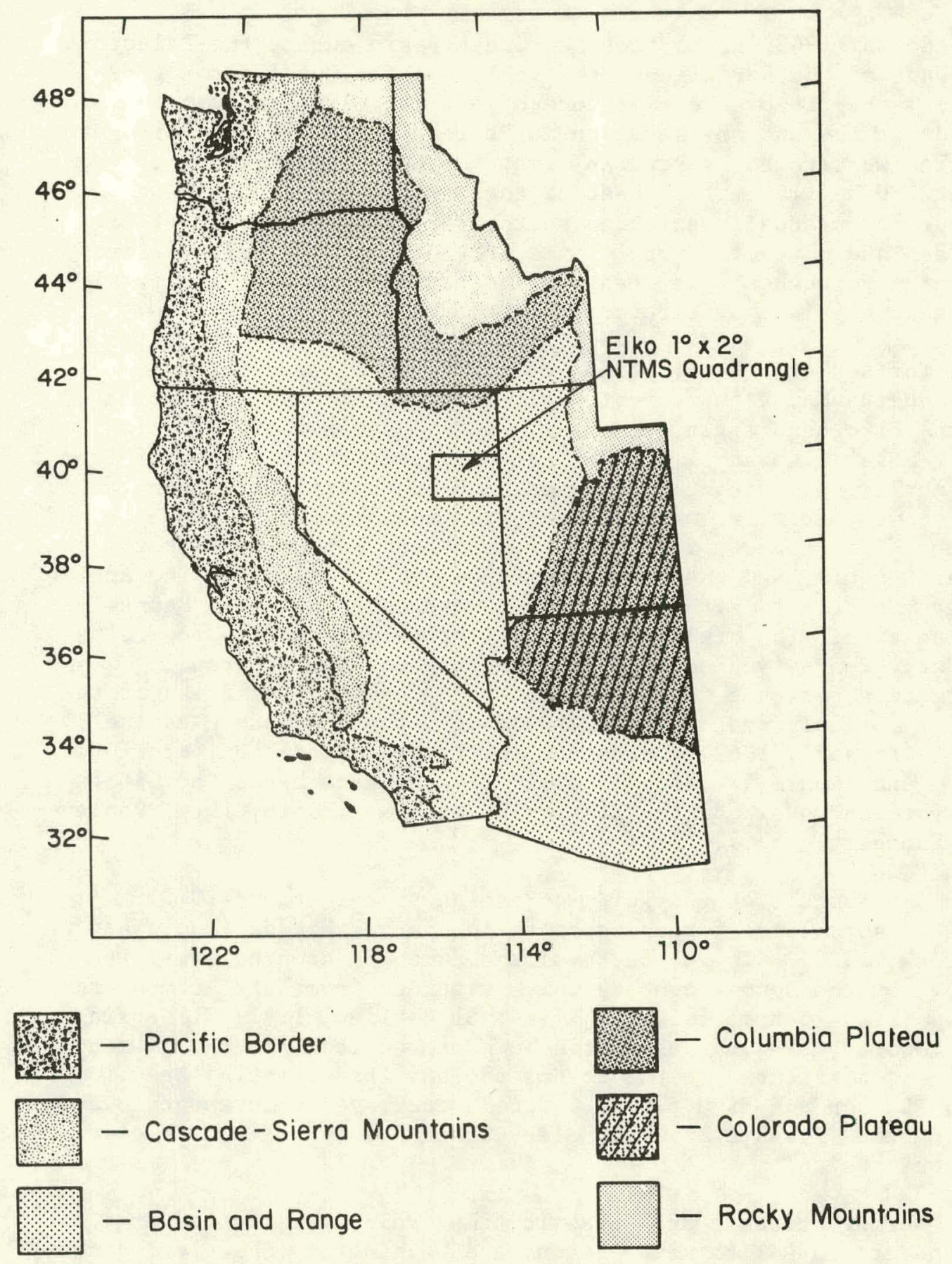

FIGURE 2. Location of the Elko Quadrangle on a Physiographic Province Map 
may be represented by an unconformity at the base of the Eureka Quartzite (Roberts and others, 1967; Nolan, 1943).

Nolan (-943) notes that the Great Basin durirg the Paleozoic was part of the Cordilleran geosyncline. The Cordilleran geosyncline was sp-it by the emergence of a geanticline in western Nevada at the end of the Devonian Period (Nolan, 19L3). This geanticlire was erodec by Permian time. A second gearticline formed about $160 \mathrm{~km}$ (100 miles) east of the earlier one in southern Nevade and g-adually extended northward throughout the rest of Permian and most of Mesozoic time. Eventually this geanticline extenced throughout the Great Basin area, creating an erosional, volcaric highland by Tertiary time.

The Antler orogeny peaked during Early Mississippian time. The Roberts Mountains thrust, which outcrops in the western part of the E-ko quadrangle, was likely active during Late Devonian to Eanly Mississippian time (Smith and Ketner, 1968). Clastics from the Antler ozogenic belt west of the Elko quadrangle pulsed into the seaway; Eorming, among others, the Chainman Sta-e (Roberts and Lehner, 1955; Brew, 1963), the Diamond Peak Formation (Roberts and others, 1967), and the Tonka Formation of Dott (1555). The Antler orogeny continued with intermittent movements into Late Pennsy1vanian time. The highlands were effectively eroded to low relief by Early Pennsylvanian time with calcareous facies extending westward across the foreland basin into the marginal areas of the uplift (Gilluly and Masursky, 1965) into the area known as the Ely basin (Bissel1, 1967). Mudstone, siltstone, sandstone, conglomeraze, and impure limestone (Antler flysch) were deposited within the fore-and basin during Mississippian time (Poole 1974; Poole and Sandberg, 1975).

The Humjolt orogery of mid-Permian time (Ketner: 1977) created some local flysch. deposits in central Neveda (Poole and Wardlaw, 1973). The deposits of the Humboldt orogen were disrupted by the Sonoma orogeny which extended from Late Permian to Early Tr-assic tine (Rcberts, 1964; Silberling, 1973; Silberling and Roberts, 1962). Deformation of Permian rocks in the Diamond Range is attributed to the Sonoma orogeny (Brew, $1961 \mathrm{~b}$; Brew, 1963; Larson and Riva, 1963). Sonoma epeirogenic movements ended during the Triassic Ere with a resultant low relief of the old orogenic belis.

During Triassic ar.d Jurassic time, volcanism erupted from an island arc it California, Oregon, and Washington (Shawe and others, 1978), creating a depositional inner-arc basin in western Nevada (Silberling and Roberts, 1962). In the Elko quadrangle, principally marine sedinents were laid down during the Tr-assic Era, followed by continental clastic sedimentation and vo-canic deposits during the Jurassic Era. The volcanic deposits may be related to volcanism from orogenic disturbances in the area of the 
Cortez Mountains just west of the Elko quadrangle (Muffler, 1964; Gilluly and Masursky, 1965). Igneous activity began at this time and continued into Early Cretaceous time (Nolan, 1962; Ferguson. and Muller, 1949; Carlson and others, 1975).

By Cretaceous time, most of the Great Basin had developed into an area of moderate highland and the Basin and Range topography of modern times began to form. The epicontinental sea of the Rocky Mountain geosyncline was located just east of the Elko quadrangle during Cretaceous time, and only rocks of the Newark Canyon Formation of terrestrial clastic origin were deposited in this quadrangle. Cretaceous-age, large-scale, eastward overthrusting took place in western Utah, just east of the Elko quadrangle in the Sevier orogenic belt (Armstrong, 1968). Cretaceous plutonism may be marginally related to a subduction zone that had formed along the west margin of the continent (Shawe and others, 1978).

Cenozoic orogenic movements consist principally of highangle faulting and tilting of Basin and Range blocks, and intermittent volcarism (Table 1). Most of the ranges of the Elko quadrangle ara tilted eastward or southeastward.

At least two stages of glaciation were present in the Elko quadrangle; the Lamoille (early Wisconsin to Iowan), and the Angel Lake (later wisconsin - Blackwelder, 1931; Sharp, 1938; and Sharp, 1942). The crographic snow-line was at about $3000 \mathrm{~m}(10,000 \Xi t)$ during Wiscorsin time with a southward gradient of 60 to $90 \mathrm{~m}$ per $160 \mathrm{~km}$ (200 to 300 feet per $100 \mathrm{miles}$ ) (Sharp, 1942).

Current radiometric age dates of the quadrangle are summarized in Table 2 .

\section{Stratigraphy}

\section{Precambrian Era}

Precambrian rocks of the Elko $1^{\circ} \times 2^{\circ}$ NTMS quadrangle consist of unnamed metamorphic rocks, the McCoy Creek Group, and possibly the lower part of the Prospect Mountain Quartzite (Misch and Hazzard, 1962). The McCoy Creek Group is exposed in the Ruby Mountains and in the Pilot Range just north of this quadrang-e. Metamorphosed rocks of the Ruby Mountains and East Humboldt Range may be of ar. older Precambrian basement, though evidence is inconclusive (Misch and Hazzard, 1962). The McCoy Creek Group consists of thick successions of quartzose and argillaceous metasediments and is over ain by the Prospect Mountain Quartzite (Misch and Hazzard, 1962). The McCoy Creek Group and Prospect Mountain Quartzite have undergone synkinematic, orogenic metamorphism of post-Cambrian age (Misch, 1960). 


\section{TABLE 1}

\section{Summary of Tertiary Igreous Events}

Age*

j to recent

$16-5$

$34-20$

$\dot{4} 0$
Activity**

Eruption of alkaline andesites ard dacites

Basalt and rhyolitic flows

Wicespread ash-flow sheets of rhyolitic eruptions

Emplacerent of small igneous bodies and eruption of andesite lavas

* Age in nillicns of years before the present (Myr BP).

** Sequence from Silbeman and McKee (1973). 
TABLE 2

Radiometric Ages of Rocks in the Elko $1^{\circ} \times 2^{\circ}$ NTMS Quadrangle

\begin{tabular}{|c|c|c|c|c|c|}
\hline Site & Formation & Rock Type & Mineral & Age & $\begin{array}{l}\text { Method/ } \\
\text { Reference } \\
\end{array}$ \\
\hline 1 & Silver Zone Pluton & Granite & Biotite & $124(5)$ & $1 / 1$ \\
\hline 2 & Humboldt Fm. & Tuff & Biotite & $36.6(0.8)$ & $1 / 2$ \\
\hline 3 & & Tuff & Biotite & $36.2(0.7)$ & $1 / 2$ \\
\hline $4 a$ & Humboldt Fm. & Tuff & Sanidine & $33.2(0.7)$ & $1 / 2$ \\
\hline 4b & Humboldt Fm. & Tuff & Biotite & $34.9(0.7)$ & $1 / 2$ \\
\hline 5 & Humboldt Fm. & Tuff & Biotite & $33.9(0.9)$ & $1 / 2$ \\
\hline 6 & Humbo:dt Fm. & Tuff & Biotite & $39.2(0.8)$ & $1 / 2$ \\
\hline 7 & & Rhyolite & Biotite & $35.5(1.4)$ & $1 / 2$ \\
\hline 8 & & Rhyolite & Biotite & $34.6(1.9)$ & $1 / 2$ \\
\hline 9 & & Quartz Monz. & Biotite & $26(4)$ & $1 / 3$ \\
\hline 10 & & Quartz Monz. & Biotite & $29-36(3.3)$ & $1 / 3$ \\
\hline 11 & Harrison Stack Pass & Quartz Monz. & Biotite & 35 & $2 / 3$ \\
\hline 12 & & Quartz Monz. & Zircon & $30(3)$ & $2 / 3$ \\
\hline 13 & & Quartz Monz. & Zircon & $40(4)$ & $2 / 3$ \\
\hline 14 & & Pegmatite & & 41.5 & $1 / 3$ \\
\hline 15 & & Pegmatite & & 29.8 & $1 / 3$ \\
\hline 16 & & Syenite & Biotite & $125(19)$ & $1 / 3$ \\
\hline 17 & & Quartz Monz. & Biotite & $140(21)$ & $1 / 3$ \\
\hline 18 & & Quartz Monz. & Biotite & $35(5)$ & $1 / 3$ \\
\hline 19 & & Quartz Monz. & Zircon & 41 & $2 / 3$ \\
\hline 20 & & Tuff & Biotite & $22(3)$ & $1 / 3$ \\
\hline 21 & Dead Horse Tuff & Tuff & Biotite & 39.9 & $1 / 3$ \\
\hline 22 & & Gneiss & Biotite & $25(4)$ & $1 / 3$ \\
\hline 23 & & Gneiss & Biotite & $29(4)$ & $-1 / 3$ \\
\hline 24 & & Granite & Zircon & $45(10)$ & $2 / 3$ \\
\hline
\end{tabular}

Explanation of columns: SITE - key to Plate 1B; AGE, in Myr BP, (--) is numerical value of uncertainty; METHOD/REFERENCE, (METHOD) 1 is $\mathrm{K} / \mathrm{Ar}, 2$ is $\mathrm{Pb} / \mathrm{A}$, (REFERENCE) 1 is McDowell (1971), 2 is McKee and others (1971), 3 is Schilling (1965). 
The Prospect Mountain Quartzite has been notec as latest Prezambrian by Hope and Ccats (1976) in their stratigraphic column. However, Wheeler and Lemmon (1939.) note that the upper $30 \mathrm{~m}$ (100 ft) of the Prospect Mountain Quartzite are Lower Cambrian basec on fossil evidence. The formation is at least $450 \mathrm{~m}$ (1500 ft) thick (Wreeler and Lemmon, 1939) and may possibly bridge the time zones. The Prospect Mountain Quartzite consists of cuartzite with a few percent feldspar and shale partings (Hose and Blake, 1976). This quartzite has undergone low-grade metamorphism which has produced sericite; the shale partings have changed locally to phyllite (Hose and Blake, 1976).

\section{Paleozoic Era}

The Cambrian system of the Elko quadrangle is represented by the Prospect Mountain Quartzite and by unnamed units: of carbonate rocks (limestor.e and dolonite) and detrital rocks (sh:le and quartzita). These may correlate to the Eldorado Dolumite Walcott, 1908) of Lower Canbrian age, the Geddes Limestone Whe $\mathrm{Wer}$ and Lemon, 1939 !, Pole Canyon Limestone (Kellogg, 1963), Secret Canyon Shale (Hague, 1892), Lincoln Peak Formation (Whitebread, 1959), the Johns Wash Limestone (Drewes and Palmer, 1957), the Dunderberg Shale (Walcott, 1908), and the Corset Spring Shale: (Drewes, 1958).

The Pogonip Grouf is of Middle to Lower Ordovician age (Hintze, 1951; Ross, 1949; 1951). Wheeler and Lemmon i1939) note Eossils of Upper Cambrian age in the lower part of the "?ogonip Limestcne." Nola.. and others (1956) redefine: the Pogonip, restricting it to the Ordovician portion only, differentiating the lower portion into the Windfall Formation of Upper Cambrian age.

The Eureka Quartzite (Hague, 1883) is a white quartzite exposed in the Riby Mountains and Cherry Creek Range iWoodward, 1964). The Eureica Quartzite is of Middle Ordovician ag? (Roberts and otjers, 1967!. Other references on the Ordoviciar zocks of the quadrangle include Chamberlin (1975), Christensen (:975), Hintze (1950), Ketner (1968), and Webb (1960).

Silurian rocks of the Elko quadrangle are made up principally of tine Laketown Dolomite which is combined with tie Ordovician Ely Springs Dolonite (Plate 1-A). Previous work in the area has combined the above two units with the Fish Haven Dolomite (Woodward, 1964; Fritz, 1960; Dechert, 1967).

The Devonian systen was affected by the Antler orogeny of Late Devonian and Mississippian time, when an orogenic highland developed along the western mergin of the Cordilleran miogeosyncline. Poole (1974) and Pcole and Sandberg (1975) rote the 
westward source for sediments that formed the Antler flysch during this time. Devonian units of the Elko quadrangle include the Gullmette Formation (Nolan, 1935), Devils Gate Formation (Merriam, 1940), Woodruff Formation, and Pilot Shale (Spencer, 1917).

Mississipplan units include the Joanna Limestone (Spencer, 1917), the Chainman Shale (Spencer, 1917), and the Diamond Peak Formation (Hague, 1883; Brew, 1961a). The Pennsylvanian system consists of rocks of the Ely Limestone (Lawson, 1906; Spencer, 1917), and the equivalent Moleen and Tomera Formations (Dott, 1955). References on the Mississippian and Pennsylvanian systems include Addison (1929), Blomquist (1971), Christensen (1975), Coogan (1962), Marcantel (1973), and Steele (1959).

The Permian system is represented by the Strathearn Formation (Dott, 1955), Sunflower Formation, Winecup Formation, Rib Hill Sandstone (Brokaw and Heidrick, 1966), Pequop Formation (Steele, 1960), and Park City Group (Hose and Repenning, 1959). Other references on the Permian rocks in the Elko quadrangle include Poole and Wardlaw (1978), Stevens (1963), Knorr (1967), and Barosh (1965).

\section{Mesozoic Era}

The Triassic Period of the Elko quadrangle is represented by marine sedimentary rocks equivalent to the Moenkopi and Thaynes Formations and by sandstone and shale equivalents of the Aztec Sandstone and Chinle Formation (Hope and Coats, 1976).

The Jurassic and Cretaceous Periods are represented by Jurassic age intrusives, Cretaceous age intrusives, and by the Cretaceous Newark Canyon Formation (Nolan and others, 1956).

\section{Cenozoia Era}

Tertiary units consist of volcanic deposits and associated volcanic sedimentary deposits erupted at intermittent times (Table 2).

\section{Geology of the Ranges (Brief Summary)}

\section{Adobe Range and Elko H111s}

The area of the Adobe Range and Elko Hills in the northwest section of the Elko $1^{\circ} \times 2^{\circ}$ NTMS quadrangle is made up of low, desert hills separated by the Humboldt River valley.. Rocks of the 
area consist principaliy of sedimentary and volcani= rocks of Miocene to Recent aze and tightly folded Paleozoic zocks. The Adobe Range contains rocks of the Diamond Peak Formarion, Chainman Shale, S=ratiearn Formation, and the Park City Grou? (Ketner, 1970). The rocks of the Elko Hills consist of the Chainman Shale, Diamond Peak Formation, and Park City Group.

Structural relations of the area indicate two episodes of thrusting and one of folding (Ketner, 1970). The oldest thrustfaulting is of Paleozoic age and the youngest is of post-Early Triassic age (Ketner, 1970). References of interest in the area inslude Evans and Ketner (1971), Ketner (1973 and 1974), and Silitanga (1974).

\section{Pinon Renge}

The Pincn Range lies along the west border of the Elko quedrangle and displays a diverse geological charazter. Among the units found here are: the Western facies, a Palejzaic overthrust sheet associated with the Roberts Mountain thrust; unnamed Paleozoic dolomitic rocks: Guilmette and Devils Gate Formations of Devonian age; Chainman Shale and the Diamond Peak Frama:ion; Ely Limestone; Strathearn Formation; Newark Canyon Fornation; Newark Canyon Formation; and volcanic rocks of Dligocene and Miocene ages. The Carlin area lies to the west of the Pinon Range where extensive studies have teen made owing to mineral ceposit (gold) interests.

The principal structural feature of the Pinon jange is the Roberts Mountain thrust, an eastward thrust of Late Levcnian age (Smith anc Ketner, 1968). References of interest in the area include Carlisle and others (1957), Gilluly and Masursky (1965), Gordon and Duncan (1961), Noland and others (1956), Boberts and Lehner (1955), Regnier (1960), Smith and Ketner (1975), Radtke (19.6), Jones and others (1978), and Flynn (1957).

\section{Diamond Mountains}

The Diamond Mounzains, located in the southwestezn area of the Elko quadrangle consist of Joanna Limestone and $P$ - lo: Shale of the White Pine Group (Misch, 1960) of Devonian and Mississippian age, Ely L-mes tone, and Fequop Formation. These marine sadimentary rocks have been inveded by a Tertiary granitoic pluton. References of interest tc this area include Dott (1555\%, 3rew (1961b), Hose and Blake (1976), Vanderburg (1936), Larson and Riva (1963), and Roberts ard athers (1967). 


\section{Ruby Mountains}

The Ruby Mountains of the west-central area of the Elko quadrangle are the highest and most extensive range in the quadrang:e. The geology of the Ruby Mountains is considerably more complex than that shown on Plate 1-A, but this complexity could not accurately be shown at the scale $(1: 250,000)$. The Ruby Mountains generally consist of Paleozoic and Precambrian metasediments intruded by Mesozoic-to-Tertiary granitoid plutons. Alpine glaciation of wisconsin age left deposits throughout the central and northern areas of the range. A large group of metamorphosed lower Paleozoic and Precambrian rocks, located in the northwest Ruby Mountains ( $P$ late $1 \mathrm{~A}$ ), is actually a complex section which has been reasonably well-defined and displayed at a scale of 1:100,000 by Hope and Ccates (1976). The Ruby Mountains are one of the principal aress displaying Ordovician age tectonism (Willden and Kistler, 1967;. Studies in the Ruby Mountains have been important to an understanding of the history of the Cordilleran geosyncline. A summary of mportant references on the area includes Armstrong and Hansen (1966), Howard (1966), Sharp (1942), Willden and others, (1966), Willden and Kistler (1967), Blackwelder (1934), Willden and Kistler (1969), Snelson (1957), Ketner (1973), Sharp (1938, 1939, 1940), and Dudley (1967).

\section{East Humboldt Range}

The East Humboldt Range, located in the north-central section of the Elko quadrangle, consists principally of metamorphosed lower Paleozic and Precambrian sediments. Glacial deposits are common in the East Humboldt Range. Pertinent references on the area include many of those of the Ruby Mountains.

\section{Wood Hï1ls and Pequop Mountains}

The Wood Hills and Pequop Mountains, situated in the northcentral part of the Elko quadrangle, consist of a wide range of Paleozoic rocks with a substantial amount of Triassic marine sedimentary rociss in the southern part of the Pequop Mountains. The portion of the Wood Hills in the Elko quadrangle consists principally of Eureka Quartzite. The dominant structural feature of the Wood Hills is the Wood Hills thrust-fault of Cretaceous age.

Two Cenozoic domes formed in the area, one under the Wood Hills and the other just west of the Pequop Mountains. The Wood Hills uplift occurred without major faulting. The Pequop Mountains are an east-tilted fault-block (Thorman, 1970). References 
on the area include Harlow (1956), Oesterling (1962), Robinson (1ऽ61), Snelson (1955), and Thorman (1962).

\section{Toano Range and Goshute Mountains}

The Toano (Toana) Fange and Goshute Mountains in the eastern part of the Elko quadrar.gle are geologically contir.uous as an east-tilted fault block. Virtually all Paleozoic units of the quatrargle are representec in these ranges. A gentle dcming of the rocks is represented by the variation in age of the expcsed units. older rocks are exposed near the northern border of the Elko quadrangle in the Toano Range, representing a dome or antiformal feature. A synformal area is represented in the central. Toano Range where Permian rock: are exposed, rising to a lonal feature in the northern Goshute Mountains where Ordovician rociss are widely exposed. The synformal area is also represented in tine southern Goskute Mountains on the limb of the domal or antiformal feature that has Pennsylvanian Eiy Limestone in wide areas of outcrop. High-angle faulting is abundant and complex in the Toano Range and Goshute Mountains. Tertiary volcanism is generally of the 17 to 6 Myr BP age group, but a large area of volcanic deposits of 41 to 34 Myr BP age is present in the southern Goshute Mountains.

References on the area include Pilger (1972), Desai (1969), Berge (1960), Messin (1973), Buckley (1967), Sayyah (1965), Steininger (1966), Slade (1961), and Berge (1960). The geology of the nearby Pilct Range is outlined by O'Neill (1968).

\section{Cherry Creek Range}

The Cherry Creek Range consists principally of Pennsylvanian and Permian rocks. An antiformal feature in the southwestern area exposed rocks of Cambrian age. The range appears to be an easttilted fault block and is located in the south-centrel portion of the Elko Quadrangle. References on the area include Acair (1961), Holmes (1950), Fritz (1968), and Nelson (1956).

\section{sntelope Renge and Dolly Varden Mountains}

The Antelope Range and Dolly Varden Mountains in the southcentral portion of the Elko quadrangle consist mostly of volcanic deposits of 41 to 34 Myr BP age with a limited amount of bedrock of Permian to Triassic age outcropping. References on the area include Avents (1961), Blake and Hose (1968), Snow (1964), and Sanderson (1972). 


\section{Schell Creek Range}

References on this area include Dechert (1963), Young (1960i, Dechert (1967), and Drewes (1967).

\section{Medicine Range}

References on this area include Collinson (1966 and 1968), Sides (1966), and Freyne (1973).

\section{Mineral Resources}

The mineral resources of the Elko $1^{\circ} \times 2^{\circ}$ NTMS quadrangle include a wide range of metallic and nonmetallic resources. Metallic resources include copper, lead, silver, tungsten, gold, zinc, and antimony.

\section{Metallic Resources}

The Delker district (Hi11, 1916; Lincoln, 1923; Granger and others, 1957) is located in the area of T.28N., R.62E. This district was ciscovered in 1894 and produced copper ore during the years 1916 and 1917 .

The Dolly Varden district (Hi11, 1916; Lincoln, 1923: Granger and others, 1957) is located in an area about $25 \mathrm{~km}$ (16 mi) northeast of Currie. The district was discovered in 1860 and produced intermittently to about 1978. The deposits of the district are contact-metarorphic and replacement deposits containing copper. lead, silver, and some gold-bearing veins. Recent production has been from the Victoria Copper mine.

The Ferber district (Hil1, 1916; Lincoln, 1923; Granger and others, 1957) is located in the area of T.17N., R.70E. The contact-metanorphic and.replacement deposits contain copper, lead, and silver. The district was discovered about 1880 and produced intermittently until about 1943.

The Ferguson Spring district (Hill, 1916: Lincoln, 1923; Granger and others, 1957) is located in the area of T.30N., R.69E. The deposits were discovered in the late $1880^{\prime} \mathrm{s}$ and little production has been seen from the district. The deposits consist of oxidized, irregular, replacement bodies.

The Harrison Pass district (Hess and Larsen, 1922; Klepper, 1944) is located in the vicinity of T.28N., R.58E. The deposits are of tungsten from tactite in a contact zone between granite and limestone. 
The Kinsley distriat (White, 1871; Whitehill, 1875; H111, 1916; Lincoln, 1923) is located in the area of T.26N, and R.67E. to R.68E. The district was discovered in 1862. The ore is found in Paleozoli sedimentary rocks of dolomitic limestone, shale, and shaly-limestone iniruded by quartz monzonite. There has been little prodiction fron the area. Gold and copper, and minor silver and lead are the principal minerals of the district.

The Lee district (Eranger and others, 1957) is located on the west side of the Ruty Mountains opposite the Rtby Valley district. Copper; silver, lead, zinc, antimony, ard trace gold were noted in quartz veins in limestone. The district has had litt1 a production.

The Mud Springs district (H11l, 1916; Lincolin, 1923) is located in T.28N., R.60E. The district was discojered in 1910. The principal mine of the district, the Silver Butte mine, was established in $19: 1$. There is no current production from the district. The ore deposits consist of galena in a barite gangue.

The Proctor district (Lincoln, 1923) is locatec in T.35N., R.68E. The district has produced small amounts of silver ore.

The Railroad district (Emmons, 1910; Van Barneveld, 1916; Lincoln, 1923; Ketner and Smith, 1963) is located 1. T.30N., R.53E. The district was Alscovered in 1869 in an atea of limestone intruded by granodiorite. The ore is principally replacement deposits of lead, silver, and copper ore in marjeized limestone. There is no current production from the district.

The Ruby Valley district (Hi11, 1916; Lincoln, i23; Granger and others, 1957) is located on the east side of the Fuby Mountains about $17 \mathrm{~km}(11 \mathrm{mI})$ north of the old Ruby Valley Post office. The district was discovered about 1903 and has produced gold, silver, copper, lead, and zinc. The ore bodles appear to be small, in limestone, and assoclated with a granitic intrusive.

Tr:a Spruce Mountain district (Raymond, 1873; Sebrader, 1931) is loceted in $T \cdot 31 \mathrm{~N}$, and R.63E. to R.6E. along the srest of the Spruce Mountains. The district produced lead, copper, and silver until the 1950's.

The Valley View district is located in T.29N., R.57E., where native bistuth was discovered in 1913. The ore consists of scheelite in limestone associated with a quartz monzonite. 


\section{Nonmetallic Resources}

Nonmetallic mineral resources are varied and abundant in the Elko quadrangle (Granger and others, 1957). Sand and gravel are abundant in the valley areas of the quadrangle, and several local deposits are currently being worked. Limestone and dolomite are plentiful in the Elko quadrangle, and Granger and others (1957) report potential for limestone suitable for use in quicklime and cement. Marble of commercial-grade dimension-stone quality is reported in the Elko quadrangle by Reid (1904). Granite for dimension-stone was quarried north of Elko prior to 1907 , and sandstone for dimension-stone was quarried near Elko (Winchester, 1923). Diatomaceous earth has been produced from the Humboldt Formation (Fulton and Smith, 1932). Small amounts of impure coal have been noted in an area just west of the Elko quadrangle in Paleozoic limestone, and lignite has been noted in the Humbcldt Formation (Schrader and others, 1917; Winchester, 1923).

Oil shale was discovered in the vicinity of the town of Elko in the 1870's (Winchester, 1923; Winfrey, 1958). Some production of oil-shale products were recorded in 1917 and 1918 (Couch and Carpenter, 1943). Several oil exploration wells have been drilled in the Elko quadrangle. An oil show was reported near Elko, and oil and gas were reported from a well near Jiggs, Nevada (still under active exploration), and south of Wendover, Nevada (Garside and Schilling, 1977).

\section{HYDROLOGY}

\section{Climate}

The climate in the Elko $1^{\circ} \times 2^{\circ}$ NTMS quadrangle is controlled by elevation and is cold during the winter months and mild during the summer months. The average July temperature is about $24^{\circ} \mathrm{C}$ and the average January temperature is about $-5^{\circ} \mathrm{C}$. The eastern portion is warmer than these averages by a few degrees. The small amount of precipitation ranges from about $127 \mathrm{~mm}$ in the east to $317 \mathrm{~mm}$ in the west (NOAA, 1977). Most of the precipitation occurs during the cooler months and occurs as snowfall in the higher elevations. Precipitation data for the months in which sampling took place are presented in Table 3.

\section{Geography}

The entire Elko $1^{\circ} \times 2^{\circ}$ NTMS quadrangle lies in the Great Basin section of the Basin and Range Province (Figure 2 and Fenneman, 1931, p. 328). Block-faulted mountains and intervening 
TABLE 3

Precipitation Totals for 1979 at Selected Weather Stations in the Elko Quadrangle

Weather station

and

Average Monthly Precipitation, mm

Elevation

Jan Feb Mar Apr May June

July Aug

Sept

Oct

Nuv Dec

Elko FAA AP

$29.5 \quad 19.6 \quad 21.1$

20.8

$21: 2$

$25.7 \quad 10.4$

15.5

8.64

16.8

25.7

28.7

(1550 m)

$31.0 \quad 30.5 \quad 32$.

29.7

30.5

$26.9 \quad 14.5$

14.2

13.7

21.3

32.8

40.4

$(1830 \mathrm{~m})$

Wendover Auto B

$7.37 \quad 7.87$

10.4

11.2

17.3

$\begin{array}{lll}18.5 & 5.59 & 9.14\end{array}$

6.86

$11.4: 10.2$

8.13 
valleys filled with detritus from the mountain slopes are characteristic. The mountains and valleys, trending roughly northward, are about equal in area.

Both Ruby Valley and Steptoe Valley have broad flat valleys at altitudes of about $1900 \mathrm{~m}$. The west side of Ruby Valley is bordered by an escarpment leading upward to Ruby Mountain (3000-m altitude). The east side of Steptoe valley is bordered by steep slopes of the Toano Range (2600-m high). Most other valley walls are less stee?, and gentle pediment slopes are common. In some places, the sloping margins of the basins are an assemblage of alluvial fans; and, in other places, bare-rock pavements are prominent. Arroyos and washes add to local irregularities in the lower mountain slopes, whereas playas and alkall flats occupy low places in several valleys. Natural vegetation is sparse; the more arid areas have scattered creosote bush, cactus, and sage brush.

There are many ranches in the area that raise cattle and sheep. Most farms use irrigation and ralse forage and grain crops to support the cattle. Some dry farming is practiced in the area.

The area has a population of about 8000 (U.S. Bureau of Census, 1970). The town of Elko, Nevada, accounts for most of the population.

\section{Dralnage and Hydrology}

The cnly perennial surface drainage into and out of the Elko quadrangle is the Humboldt River, which flows southwestward through the northwest part of the area. Ephemeral streams of the mountains, carrying occasional rainwash and snowmelt, lose their water as downward percolation in the alluvium. Most lakes in the area are dry during summer months. The average discharge or 40 years for dumboldt River near Elko is $6.68 \mathrm{~m}^{3} / \mathrm{sec}\left(236 \mathrm{ft}^{3} / \mathrm{sec}\right)$, and the average discharge for 29 years for South Fork Humboldt River (near Elko) $1 \mathrm{~s} 3.285 \mathrm{~m}^{3} / \mathrm{sec}\left(116 \mathrm{ft}^{3} / \mathrm{sec}\right.$ ).

All cf the consolidated rocks are fractured to varying degrees and are capable in most places of ylelding some water to wells. The carboniferous carbonate rocks are much more permeable than are the Tertiary intrusive rocks.

All of the alluvial valleys have permeable sands and gravels and have large amounts of ground water in storage. Ruby Valley is the largest, having no groundwater outflow but very significant evapotrarspiration within it. Ground water recharge is reported to be abcut 84 million cubic meters $(68,000$ acre-feet) per year. Goshute and Antelope Valleys also have significant alluvial aquifers (Eakin and others, 1976). However, the average permeability 
of the sediments of the valley-fill of Goshute-f.ntelope Valley, as well as that of sediments in the other valleys, is thought to be relstively low because fine-grained lake sedimert the valley fill. Some of the irrigation wells th:t penetrate the more permeable zcnes yield as much as 1300 liters fer minute.

The runoff originating in the mountains sinks. into the ground as it passes over the alluvium at the edges of the alluvial basins (McGuiness, 1963, ?. 507). Only after heavy stonns does the water travel far over the surface of the valleys. Springa are not uncommon along the lower slopes of the mountains, sucb springs represent concentrated discharge points of water from the fracturec rocks in the mountains.

The depth of the water table is as close as 4 or 5 meters below land surface in the low valley areas, and these areas are aiso the lowest elevations of the water table. From these low places in the valleys, the water table rises toward the valley edges and further towazd the center of the mountair.s; yet, the land surface rises even nore rapidly so that the de?th of the water table increases outward from the centers of the valleys.

The quality of surface waters varies accordirg to the extent of evepotranspiration anc inflow of mineralized thermal water in the respective drairage tasins. Thus, water from the small creeks of the mountains is relatively low in mineral mattez, whereas total solids in the water in the Humboldt River increases progressively dcwn stream.

Kost of the springs discharge water having less than $500 \mathrm{mg} / \mathrm{L}$ of solids, although the few thermal springs are highly mineralized. Acceptable water for domestic use and irrigation is widespread, and water containing more than $1000 \mathrm{mg} / \mathrm{l}$ is not common. In addition to the total salt content being objectionable in some cases, excessive amounts of iron, manganese, fluoride, and scron are troublesome. locally.

Most surface waters are of good quality until they reach the closed lakes and flats where evaporation occurs. The larger rivers that are used extensively for irrigation rarely have dissolved solid content greater than $500 \mathrm{mg} / \mathrm{L}$, which is the residt of leaching and fertilizer. 


\section{FACTORS AFFECTING THE DATA}

Sediment and ground water samples and associated site data were collected during July and August of 1979. Sediment samples were collected from dry strams, a few wet streams, and soils. Most of the ground water samples were collected from springs in the more mountainous areas. The well-water samples were collected near the few doellings in the quadrangle.

\section{QUALITY ASSURANCE}

\section{Sample Collection}

Sampling teams marked each sampling site on an SRL-approved map and completed a Field Data Form (Figure 3) for every sampla. At least five percent of sampled sites were routinely checked by SRL personnel to ensure that the reported field locations were accurate. No evidence has been discovered of deliberate malfeasance by the sampling teams. In addition, 105 sediment and 15 ground-water sampling sites were field-checked by an SRL subcontractor during December 1979. A11 but three (97\%) of the sites checked were found to be located within $800 \mathrm{~m}(0.5 \mathrm{mi})$ of the locations platted on sample maps. Thus, the goals of a regional reconnaissance have not been compromised by map errors. Details of the quality assurance program are given elsewhere (SRL-138).

\section{Analytical Seandards}

Sediment Standards SRL 2.2, 3.1, and 4.1 were analyzed along with NURE sediment samples to provide precision data and routine checks for the analytical equipment and software. Tahles 4a: $4 \mathrm{~b}$, and $4 c$ contain the results from the standards run during the same time period as the Elko sediment samples. These results give a good estimate of the precision of the data and can be used in estimating bias between this and other SRL reports.

Periodically, DOF intersite comparison standards are analyzed. An independent quality assurance program hased on these standards is conducted for DOE by Ames (Iowa) Laboratory (D'Silva, et al.).

\section{DESCRIPTION OF DATA TABLES}

This section of the report summarizes the types of data tabulated on microfiche. Detailed descriptions of the tables and definitions of abbreviations can be found on the microfiche 


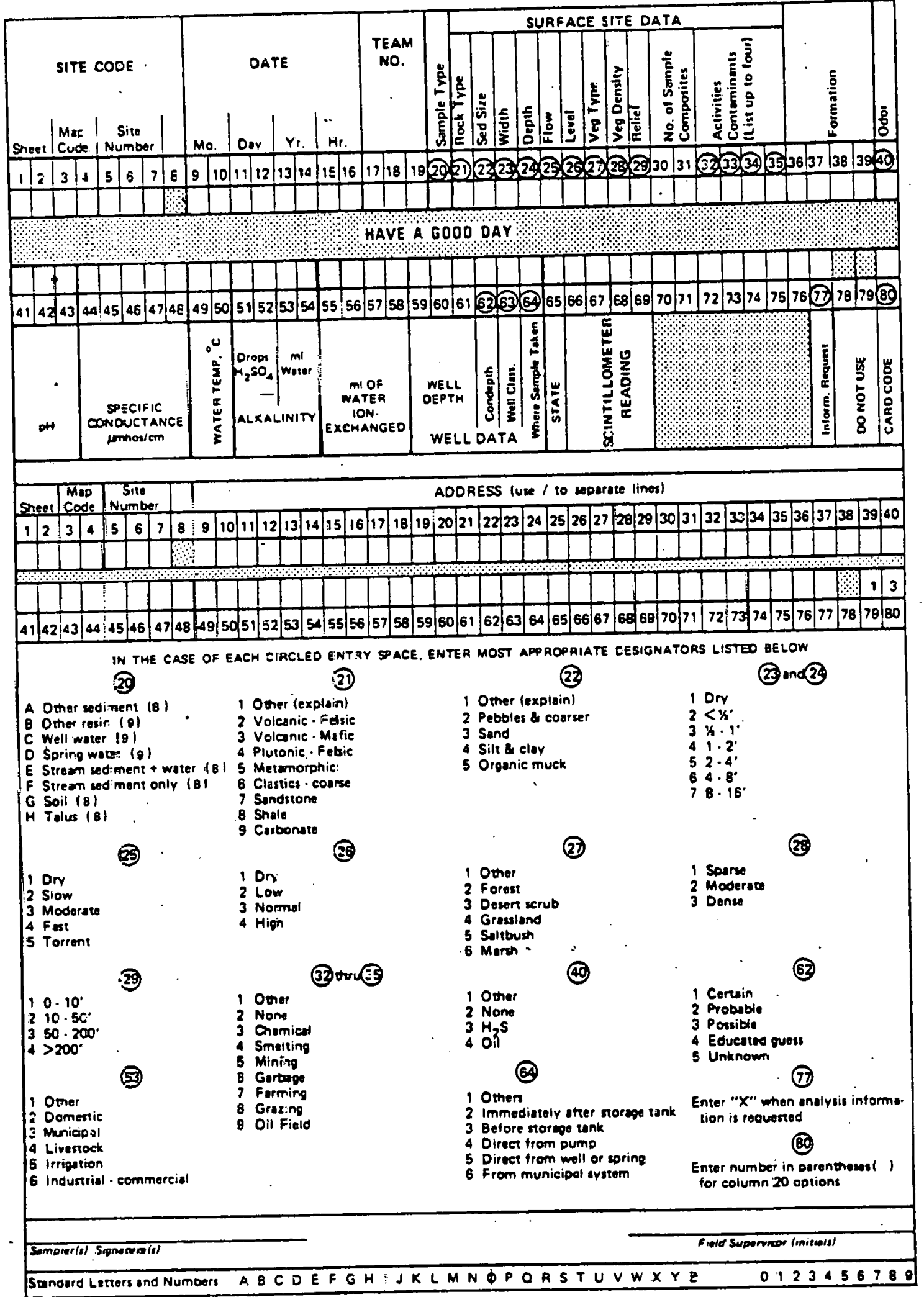

FIGURE 3. SRL Field Data Form for Westerz Quadrangles 


\section{TABLE $4 a$}

Accuracy and Precision of Analyses of SRL Standards

a. Sediment Stardard SRL 2.2

\begin{tabular}{|c|c|c|c|c|c|}
\hline Element & Number & $\begin{array}{l}\text { Mean, } \\
\text { ppm }\end{array}$ & $\begin{array}{l}\text { Coefficient of } \\
\text { Variation, \% }\end{array}$ & $\begin{array}{l}\text { Accepted } \\
\text { ppm }\end{array}$ & Value, \\
\hline $\mathbf{U}$ & 30 & 21.0 & 17.4 & 22.2 & \\
\hline Th & 25 & 109 & 13.4 & 125 & \\
\hline $\mathrm{HF}$ & 26 & 123 & 20.6 & 173 & \\
\hline Al & 30 & 6850 & 23.7 & 6500 & . \\
\hline $\mathrm{Ce}$ & 22 & 497 & 15.2 & 614 & \\
\hline $\mathrm{Fe}$ & 25 & 8570 & 22.6 & 6700 & \\
\hline Mn & 30 & 246 & 13.8 & 300 & \\
\hline Sc & 28 & 2.7 & 31.5 & 3.9 & \\
\hline $\mathrm{Na}$ & 29 & 130 & 39.6 & 145 & \\
\hline $\mathrm{T} i$ & 30 & 11,100 & 16.3 & 13,200 & \\
\hline $\mathrm{V}$ & 30 & 31 & 16.5 & 34.7 & . \\
\hline Dy & 30 & 18 & 39.3 & $<22$ & \\
\hline Eu & 18 & 2.5 & 50.6 & 2.5 & $\checkmark$ \\
\hline La & 25 & 289 & 28.4 & 301 & \\
\hline $\mathrm{Lu}$ & 22 & 2.3 & 15.3 & 2.9 & \\
\hline $\mathrm{Sm}$ & 25 & 45 & 39.5 & 51.3 & \\
\hline $\mathrm{Yb}$ & 22 & 14.6 & 23.4 & 18.2 & \\
\hline
\end{tabular}




\section{TABLE 4b}

Accuracy and Precision of Analyses of SRL Standarç

b. Sedimert standard SRL 3.1

\begin{tabular}{|c|c|c|c|c|c|}
\hline Element & Number & $\begin{array}{l}\text { Mean, } \\
\text { ppon }\end{array}$ & $\begin{array}{l}\text { Coefficient of } \\
\text { Variation, } \% \\
\end{array}$ & $\begin{array}{l}\text { Accepted } \\
\text { ppm. }\end{array}$ & Value, \\
\hline U & 23 & 42.5 & 18.7 & $41 . \Xi$ & \\
\hline Th & 26 & 135 & 22.1 & 162 & \\
\hline $\mathrm{Hf}$ & 15 & 6.5 & 40.4 & 7.4 & \\
\hline Al & 28 & 32,300 & 16.6 & 30,600 & \\
\hline $\mathrm{Ce}$ & 21 & 773 & 14.0 & 903 & \\
\hline $\mathrm{Fe}$ & 26 & 16,700 & 29.4 & $15,2 \mathrm{CO}$ & \\
\hline Mn & 28 & 229 & 15.2 & 289 & \\
\hline Sc & 26 & 3.9 & 27.2 & 4.19 & \\
\hline $\mathbf{N a}$ & 28 & 840 & 14.7 & 901 & \\
\hline $\mathrm{Ti}$ & 24 & 5100 & 23.0 & 6100 & \\
\hline V & 27 & 42 & 14.4 & 54.4 & \\
\hline$D_{y}$ & 27. & 42 & 39.2 & 50 & \\
\hline Eu & 21 & 4.2 & 50.3 & 3.86 & \\
\hline La & 26 & 391 & 16.1 & 443 & . \\
\hline Lu & 21 & 4.0 & 12.4 & 4.4 & \\
\hline Sm & 23 & 62 & 43.7 & 69.2 & \\
\hline $\mathrm{Yb}$ & 22 & 28 & 16.9 & 29.9 & \\
\hline
\end{tabular}


TABLE 4C

Accuracy and Precision of Analyses of SRL Standards

c. Sediment Standard SRL 4.1

\begin{tabular}{|c|c|c|c|c|c|}
\hline Element & Nimber & $\begin{array}{l}\text { Mean, } \\
\text { ppm }\end{array}$ & $\begin{array}{l}\text { Coefficient of } \\
\text { Variation, } \% \\
\end{array}$ & $\begin{array}{l}\text { Accepted } \\
\text { ppm }\end{array}$ & Value, \\
\hline $\mathrm{U}$ & 28 & 0.5 & 15.6 & 0.58 & \\
\hline $\mathrm{Th}$ & 13 & 3.2 & 28.9 & 2.1 & \\
\hline $\mathrm{HE}$ & 25 & 3.0 & 36.5 & 4.4 & \\
\hline Al & 28 & 57,800 & 16.5 & 66,700 & \\
\hline $\mathrm{Ce}$ & 15 & 54.6 & 32.4 & 44 & \\
\hline $\mathrm{Fe}$ & 28 & 78,000 & 9.4 & 87,300 & \\
\hline Mn & 24 & 1650 & 20.4 & 1970 & \\
\hline $\mathrm{Sc}$ & 28 & 13.8 & 28.3 & 21 & \\
\hline $\mathrm{Na}$ & 27 & 16,300 & 15.5 & 16,100 & \\
\hline $\mathrm{Ti}$ & 23 & 21,700 & 26.5 & 25,200 & \\
\hline $\mathrm{V}$ & 27 & 225 & 17.5 & 273 & \\
\hline Dy & 3 & 2.2 & 37.0 & $<22$ & \\
\hline $\mathrm{Eu}$ & 20 & 1.3 & 37.4 & 1.16 & \\
\hline La & 23 & 15.3 & 19.7 & 18.6 & \\
\hline $\mathrm{Lu}$ & 16 & 0.2 & 30.3 & 0.28 & \\
\hline $\mathrm{Sm}$ & 22 & 2.8 & 24.9 & 4.2 & \\
\hline $\mathrm{Yb}$ & 7 & 2.4 & 33.0 & 1.6 & \\
\hline
\end{tabular}


labeled OSER'S GUIDE. Ground-water analyses and site descriptions are tabulated in Teb-es $\mathrm{A}-1$ and $\mathrm{A}-2$, both of which can be found on tie microfiche titled BLRO TABLES. Sediment enalyses and site descrip$t$ ions are tabulated in Tables $B-1, B-2$, and $B-3$, which are also on the microfiche titled ELRO TABLES.

Table A-1 begins with the sample's SRL identification number, which is composed of four letters and a three-digit number. The fizst two letters identify the quadrangle from which the sample was collezted. EK is the two-letter designator Eor the Elko $1^{\circ} \times 2^{\circ}$ NTMS quadrargle. The third and fourth letters define which 15-ainute quadrengle contains the sampling site (see chart below).

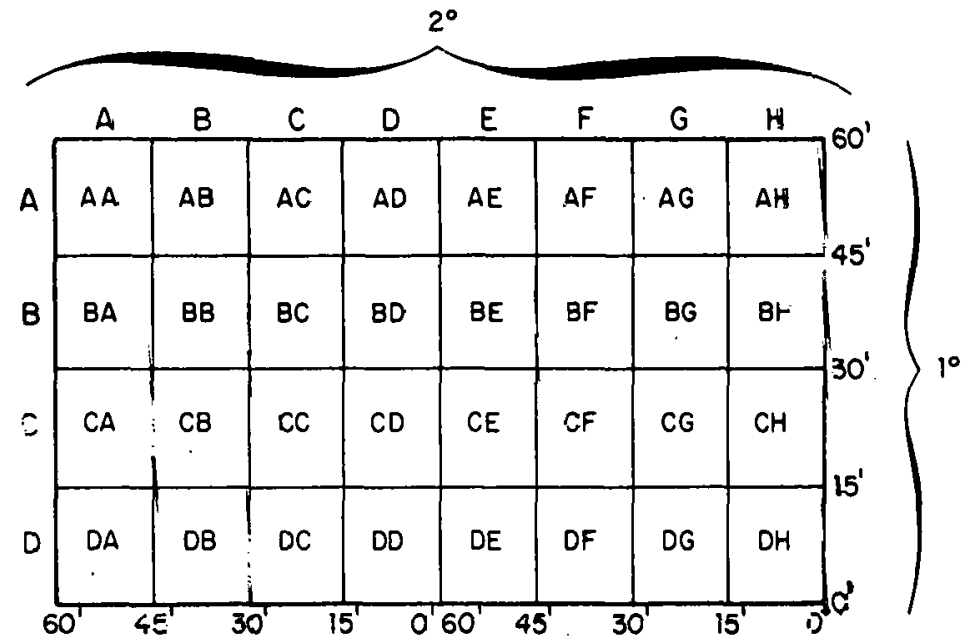

Numbers from 001 to: 499 designate surface sites. Numbers from 501 to 999 designate ground-water sites. Th? first sediment sample, therefore, taken from the extreme northeastarn portion of the E1ko $1^{\circ} \times 2^{\circ}$ NTMS quadrangle would be EKAHO01.

Ther entries on Table A-1 include a DOE idertification number; $\mathrm{pH}$, conductivity, alkalinity, and scintillometer readings; analyses for $\mathrm{U}, \mathrm{Br}, \mathrm{Cl}, \mathrm{F}$, He, $\mathrm{Mn}, \mathrm{Na}$, and $\mathrm{V}$; and the ratio of uranium-to-conductivity (multiplied by 1000 for convenience; $\mathrm{U} \times 1000$ (cond.). All entries are self-explanatory except those noted below (see OSER'S GUIDE also).

DOE ID i.s a 28-digit number that includes the following parts : 
Digit Number

1-2 State (See Table 1 in the OSER'S GUIDE)

4-10 Latitude of site

12-19 Longitude of site

21 Laboratory code $(4=$ SRL $)$

23-24 Sample type (See Table 2 in the OSER'S GOIDE)

26-28 Replication code. Generally only original samples $(-000)$ are reported in the Data Reports.

Table A-2 shows SRL identification number; concentrations of $A 1$, Dy, and Mr; sampling date; sample collection team number; and the following characteristics of the well or spring that was sampled:

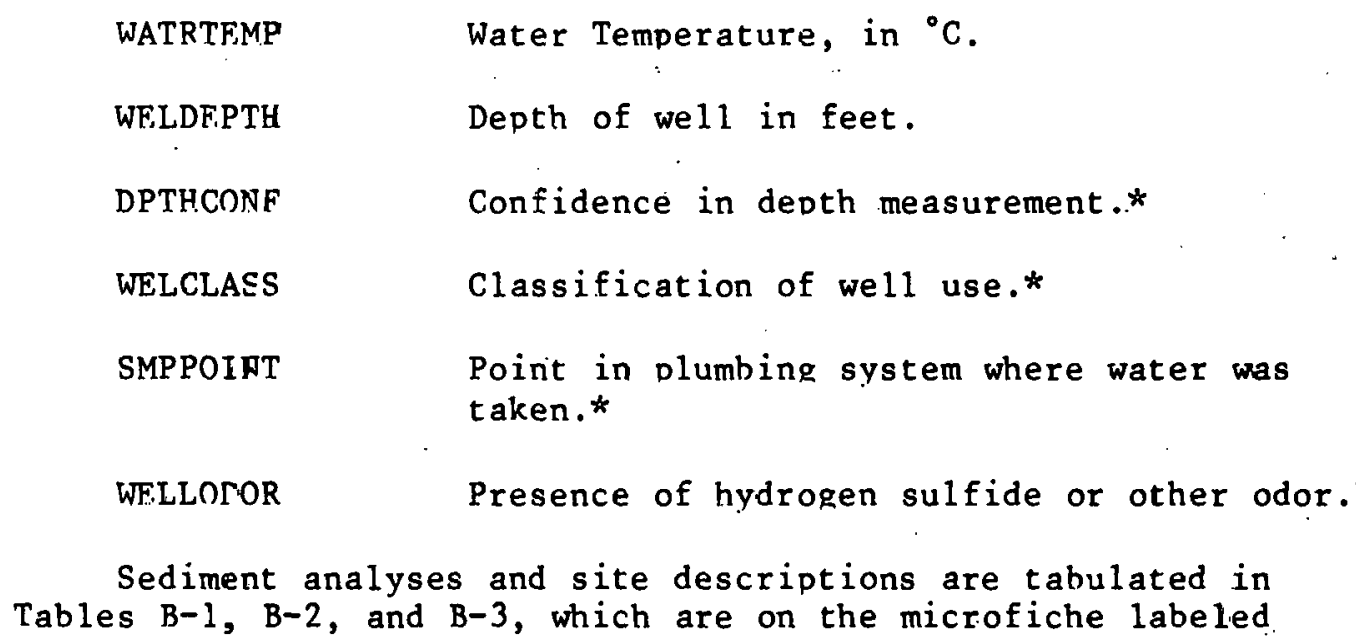

Table $B-1$ includes $S R L$ and $D O E$ identification numbers similar to those described above for ground-water sites. Table B-l also includes scintillometer readings, $\mathrm{pH}$, conductivity, and alkalinity of stream water, plus elemental concentrations of $\mathrm{U}$, Th, l.f, $\mathrm{Ce}$, $\mathrm{Fe}, \mathrm{Mn}, \mathrm{Na}, \mathrm{Sc}, \mathrm{Ti}$, and $\mathrm{V}$.

Table B-2 (Supplementary Data - Sediments) includes the SRL identification number and concentrations of Al, Dy, Fu, La, Sm, $\mathrm{Yb}$, and $\mathrm{u} \mathrm{u}$.

\# Definitions of entries under these headings are detailed in the USER'S GUIDE. 
Table B-3 (Supplementary Data - Sediments) insludes the SRL identificetion number and the following entries:

\begin{tabular}{|c|c|}
\hline SAMPTYPE & $\begin{array}{l}\text { Type of soil, sediment, etc., sampled (see } \\
\text { Table } 2 \text { in the OSER's GOIDE!' }\end{array}$ \\
\hline ROCKT:PF & Type of rock underlying sampling site.* \\
\hline SEDSIZE & $\begin{array}{l}\text { Dominant size of particles in sediment at } \\
\text { site.* }\end{array}$ \\
\hline $\begin{array}{l}\text { STRWIDTH } \\
\text { STRDEPTH }\end{array}$ & $\begin{array}{l}\text { Size and flaw rate of stream at sampling } \\
\text { site.* }\end{array}$ \\
\hline $\begin{array}{l}\text { STRFLOV } \\
\text { STRLFVEL }\end{array}$ & \\
\hline VEGTYPE & Dominant type of vegetation at site.* \\
\hline PF.GDENS & legetation density at site. \\
\hline RELIEF & Local relief at site.* \\
\hline C.DMPOSIT & Number of subsamples blended into sample.* \\
\hline $\begin{array}{l}\text { CONTAMN1 } \\
\text { CONTAMN2 }\end{array}$ & $\begin{array}{l}\text { Act-vities or contaminants that may affect } \\
\text { the material sampled.* }\end{array}$ \\
\hline $\begin{array}{l}\text { CCNTAMN3 } \\
\text { CONTAMN4 }\end{array}$ & \\
\hline FRMATION & The rock formation that under!ies the site.* \\
\hline ODOR & Odors detected in sampled mater:al.* \\
\hline WATERTEMP & Water temperature in ${ }^{\circ} \mathrm{C}$. \\
\hline SAMPDATE & Date sample was collected. \\
\hline TEAM & $\begin{array}{l}\text { Wumerical designator of sample collection } \\
\text { team. }\end{array}$ \\
\hline
\end{tabular}

Site descriptions and field measurements are recorded on the SRL Field Data Form (Figurz 3). Data are recorded in the spaces numbered 1 through 80 . The spaces have self-explanatory labels. Spaces whose numbers are circled are filled with one of the choices

* Detinitions of entries under the headings are detailed in the USER'S GUIDE. 
listed beneath the appropriate number on the Field Data Form. Some data are listed differently on the Field Data Form and in the data tables on microfiche. For example, well water samples are coded as Sample Type " $C$ " on the Field Data Form and are reported as Sample Type "52" in Table A-1. Details of how the Field Data Form is used can be found in the USER'S GUIDE and in Price and Jones (1979).

\section{Elemental Analyses}

The elements after uranium are generally listed alphabetically. Concentrations of each element are reported in parts per million (ppm) by weight for sediment samples and parts per billion (ppb) for water samples. Values have been rounded to appropriate significant figures. Note that elemental (not oxide) concentrations are quoted in this table. Values below detection limits are indicated by a minus ( - ). For example, -3 means that the sample contains less than $3 \mathrm{ppm}$ of that element. If background is high, a period (.) is used to indicate that the element was not detected, and that an estimate of the detection limit is not available for that element. Missing data are indicated by " $M$ ". All analytical results are missing when there was insufficient sample for analysis.

\section{RESULTS AND DISCUSSION OF THE DATA}

\section{Surface Sedigent Samples}

Sediment samples were collected from 1713 surface sites in the E.1ko $1^{\circ} \times 2^{\circ}$ NTMS quadrangle. Basic statistical data for uranium and 16 other elements in these sediments are given in Table 5. Log histograms, cumulative frequency plots, and areal distribution maps for these 17 elements as well as elemental ratios (U/Th and $\mathrm{U} / \mathrm{Hf}$ ) are shown on the microfiche sediment plots.

SRL ezperience suggests that most uranium in surface sediment samples is present in resistate minerals. Interpretation of the areal distribution of uranium (Plate 4 ) is best done by studying the areal distributions of the ratio of uranium to geochemically associated elements such as $\mathrm{Th}, \mathrm{Hf}(\mathrm{Zr}), \mathrm{Ce}$, etc. Elementai associations suggested here should be considered speculative pending detailed mineralogical investigations.

An areal distribution map of uranium concentrations in a given stream sediment sample may be more dependent on stream gradient or sampling conditions than on any proximity to a commercial uranium deposit. For example, if uranium were uniformly present in the mineral zircon at a concentration of $5000 \mathrm{ppm}$, then a uranium distribution map for stream sediment samples comprised of particles 
TABLE 5

Statistical Summary of

Elemental Analyses - Sediments; Elko

\begin{tabular}{|c|c|c|c|c|c|}
\hline Element & $n *$ & $\begin{array}{l}\text { Measired } \\
\text { Mex. } \star \star \\
\end{array}$ & $\begin{array}{l}\text { Values } \\
\text { Min. } t \\
\end{array}$ & Log Meantt & $\begin{array}{l}\text { Log Std. } \\
\text { Eejiation }\end{array}$ \\
\hline U & $1 \in 94$ & 67.5 & 0.7 & 0.47 & 0.16 \\
\hline Th & 1689 & 124 & 2 & 1.06 & 0.13 \\
\hline Hf & 1536 & 36 & 1 & 0.73 & $0.2:$ \\
\hline Al & 1707 & 08,400 & 15,000 & 4.67 & 0.14 \\
\hline $\mathrm{Ce}$ & 1629 & 415 & 10 & 1.76 & $0.1 T$ \\
\hline $\mathrm{Fe}$ & 1689 & 81,700 & 6200 & 4.36 & 0.14 \\
\hline Mn & 1643 & 4270 & 80 & 2.70 & 0.14 \\
\hline $\mathrm{Na}$ & 1690 & 96,800 & 1200 & 4.01 & 0.18 \\
\hline Sc & 1695 & 14.1 & 0.8 & 0.69 & 0.15 \\
\hline $\mathrm{Ti}$ & 1411 & 14,300 & 700 & 3.56 & $0.1 ?$ \\
\hline v & 1700 & 280 & 9 & 1.70 & 0.16 \\
\hline Dy & 620 & 44.4 & 0.1 & 0.50 & 0.36 \\
\hline Eu & 741 & 7.5 & 0.3 & 0.09 & 0.22 \\
\hline $\mathrm{La}$ & 1693 & 198 & 6 & 1.43 & 0.16 \\
\hline $\mathrm{Lu}$ & 1359 & 1.4 & 0.1 & -0.56 & 0.17 \\
\hline Sm & 1678 & 53 & 1.0 & 0.52 & 0.18 \\
\hline$Y_{3}$ & 765 & 11.3 & 0.7 & 0.35 & 0.17 \\
\hline
\end{tabular}


of less than 149 micrometers would have highs and lows which were functions of many factors. These include: (1) the areal distribution of zircon, (2) the areal distribution of zircon grain size, (3) the effectiveness of sampled streams in sorting and concentrating zircon relative to diluent minerals such as quartz or micas, and (4) the effectiveness of the sampling method in obtaining "representative" samples.

On the other hand, comparison of a map showing the distribution of uranium vith a map showing the distribution of the U/Hf (or $U / Z r$ ) ratio should show where zircon is an important contributor to the amount of uranium. The areal distribution of this ratio is presented on microfiche. The ratio of U/Hf should be low where zircon is the primary mineral host of uranium in sediment samples. High values of the ratio indicate areas where uranium is present in minerals other than zircon or where zircon is particularly enriched in uranium.

Using the same logic, areas where values of the U/Th ratio (on microfiche) are high show either that uranium is present in minerals other than resistates (such as monazite) or that these resistates are particularly enriched in uranium. Anomalous areas which persist on several ratio figures may be areas where uranium is present in some mineral other than common resistate minerals. If these anomalous areas are supported by other considerations (such as radioactivity highs, geologic conditions, or high values of dissolved uranium in natural waters), then they may warrant a detailed fielc examination or detailed geochemical sampling.

Several areas within the Elko quadrangle have relatively high uranium concentrations in the sediment samples. The largest such area, in the central portion of the Ruby Mountains (see areal distribution mafs on microfiche), consists of lower Paleozoic sediments intruded by Mesozoic and Tertiary granitic plutons. Some of the sediment samples have high $U / T h$ and $U / H f$ ratios. Several of the ground water samples from this area have relatively high uranium and zelium concentrations. All of these factors suggest that within this area there is significant uranium mineralization which is not within resistate mineral:s.

A small uranium anomaly is located in the extreme southeastern corner of the $15^{\prime}$ map unit CE. This anomaly persists on the U/Th and U/Hf ratio plots. This area has some of the only outcrops of the Aztec Sandstone and Chinle Shale in the Elko quadrangle. Uranium is mined from these formations in other areas. 
Sediment samples from the Dolly Varden Mounteins contain some anomalous tranium conzentrations. These samples ray be associated with a Cretaceous granitic intrusive unit in these mountains. The samples also have anonalous thorium concentrations, suggesting that rost of the uranium may be held within monazite crystals.

\section{Stream and Ground Water Samples}

Water samples wera collected from 154 ground water sites in the Elko quadrangle. A statistical summary of key field measurements and elemental analyses for ground water sites is given in Table 6. Log histograns, cumulative frequency plots, and areal distribuiion plots 三or uranium and ten other elemerts ( $\mathrm{Al}, \mathrm{Br}, \mathrm{Cl}$, Dy, $F$ : He, $M z, M n$, Ma, and $v$ ) in ground waters are shown on microfizhe. Helium concentrations were determined by mass spectrographic analyses.

Uranium concentrations in stream and ground water samples are dependent on several factors: (1) the concentration of uranium in the rocks and soils through which the ground water passes, (2) the rate at which uranium-bearing minerals in the rocks (soils) release uranium, (3) the hydrologic character of the rocks (soils), and ( 4 ; the chemistry of the water (especially $\mathrm{Eh}, \mathrm{pH}$, and aikalinity).

The interpretation of uranium analyses in natural waters is not straightforward. In active roll-front deposits, solubility of urar:ium may be low. Joncentrations of uranium in natural waters may be rery low neaz areas of active uranium deposition or very high in oxidizäng zones near dissolving ore bodies.

Urenium concentretions in water can be expected to vary with total dissolved solids in the water. Because conductivity of wate = increases with increasing total dissolved solijs, the ratio of uranium concentration to conductivity gives an ap? =ximation of the proportion of uranium is natural waters. The areal distribution of uranium concentration/conductivity ratios for ground water and stream water are shown on the ground-water and stream-water plots on microfiche.

Interpretation of the ground-water analyses is tenuous due to the scarcity and spacing of the 154 samples collected. The sites with anomalcus relium and uranium concentrations are in areas with anomaious sediment samples. 


\section{TABLE 6}

Statistical Summany of Field Measurements and Blemental Analyses - Ground Water; Blko

\begin{tabular}{|c|c|c|c|c|c|c|c|}
\hline Variable & $n *$ & $\frac{\text { Measured }}{\text { Max.** }}$ & $\frac{\text { Values }}{\text { Min. }{ }^{\dagger}}$ & Meantt & $\begin{array}{l}\text { Log } \\
\text { Mean }\end{array}$ & $\begin{array}{l}\text { Log Std. } \\
\text { neviation } \\
\end{array}$ & $\begin{array}{l}\text { Standard } \\
\text { Deviation } \\
( \pm 1 \sigma)\end{array}$ \\
\hline $\mathrm{DH}$ & 154 & 10.3 & 6.4 & 7.72 & & & 0.61 \\
\hline Conductivity & 154 & 2550 & 65 & & 2.49 & 0.24 & \\
\hline Alkalinity & 154 & 18 & 0.4 & & 0.48 & 0.23 & \\
\hline $\mathrm{U}$ & 153 & 53.4 & 0.02 & & 0.31 & 0.59 & \\
\hline Al & 131 & 7600 & 81 & & 2.39 & 0.39 & \\
\hline $\mathrm{Br}$ & 101 & 2130 & 13.6 & & 2.07 & 0.37 & \\
\hline$C 1$ & 154 & $1,150,000$ & 11,600 & & 4.49 & 0.29 & \\
\hline Dy & 9 & 4.3 & 0.05 & & -0.55 & 0.63 & \\
\hline $\mathrm{F}$ & 123 & 5100 & 18 & & 2.20 & 0.45 & \\
\hline $\mathrm{He} \pi$ & 148 & 310 & 2.3 & & 0.78 & 0.23 & \\
\hline $\mathrm{Mg}$ & 143 & 61,000 & 1160 & & 4.04 & 0.36 & \\
\hline $\mathrm{Mn}$ & 14 & 3.57 & 19.6 & & 2.13 & 0.32 & \\
\hline $\mathrm{Na}$ & 154 & 640,000 & 5420 & & 4.32 & 0.36 & \\
\hline V & 90 & 100 & 0.8 & & 0.68 & 0.40 & \\
\hline
\end{tabular}

* Number of observations. Some values are missing for reasons other than being below detection limit.

** Elemental concentrations in DDb; conductivity in $\mu_{m h o s} / \mathrm{cm}$; alkalinity in mea/L.

$\dagger$ Minimum or detection limit.

$\dagger$ Mean of values above detection limit.

1 Log units; $\left[\left(\Sigma \log _{10}, x\right) / n\right]$.

19 Helium in ppm by volume in $2 \mathrm{~mL}$ air gap over $200 \mathrm{~mL}$ of water. 


\section{ACRVOWLEDGMENTS}

The geologic and mineral occurrence maps and information in this report were compiled for SRL by David E. Howell of Reno, Nevada. The hydrologic information was provided by Harry $E$. LeGrand, of Raleigh, North Carolina. 
Adair, D. H., 1961, Geology of the Cherry Creek District, Nevada: M.S. Thesis, Utah, Univ., Salt Lake City, Utah.

Addison, C. C., 1929, Stratigraphy and Correlation of Some Carboniferous Sections of Nevada and Adjacent States: M.A. Thesis, Stanford Univ., Palo Alto, California.

Armstrong, R. L. : 1969, Sevier Orogenic Belt in Nevada and Utah: Geol. Soc. Amer. Bull., Vol. 79, Pp. 429-458.

Armstrong, R. L,, and Hansen, E., 1966, Cordilleran Infrastructure in the Eastern Great Basin: Amer. J. Sci., Vol. 264, Pp. 112-127.

Avents, J. C., :961, Geologic Map of the Antelope Range, Northeastern White Pine County, Nevada: M.S. Thesis, Washington Univ., Seactle, Washington.

Barosh, P. J., 1965, Lower Permian Stratigraphy of Bast-Central Nevada anc Adjacent Otah: Ph.D. Thesis, Univ. of Colorado, Boulder, Colorado.

Berge, J. S., 1960, Stratigraphy of the Ferguson Mountain Area, E1ko County, Nevada: M.A. Thesis, Brigham Young Univ., Provo, Utah.

Bissel1, H. J, , 1967, Pennsylvanian and Permian Basins in Northwestern Utah, Northeastern Nevada, and South-Central Idaho: Amer. Assoc. Petroleum Geol. Bul1., Vol. 51, pp. 791-802.

Blake, M. C., Jr., and Hose, R. K., 19.68, Petrology of Tertiary Volcanic Rocks, Southern Antelope Range, White Pine County, Nevada (Ab8.): Geo. Soc. Amer. Spec. Paper 101, p. 388.

Blackwelder, E., 1931, Pleistocene Glaciation in the Sierra Nevada and Basin Ranges: Geol.Soc. Amer. Bull., Vol. 42, pp. $865-922$.

Blackwelder, E., 1934, Supplementary Notes on Pleistocene Glaciation in the Great Basin: J. Wash. Acad. Sci., Vol. 24, pp. 217-222.

Blomquist, J. T., 1971, Current Directions in the Diamond Peak Formation, an Upper Mississippian-Lower Pennsylvanian Clastic Wedge, East-Central Nevada: M.S. Thesis, Univ. of Nevada, Reno, Nevada. 
Brew, D. A., 196ia, Lithologic Character of the Diamond Peak Formation (Mississippian) at the Type Locality, Eureka and White Pine Counties, Nevada: U.S. Geol. Surv. Prof. Paper 424-c, pp. C110-C112.

Brei, D. A., 1961b, Relation of Chairman Shale to Bald Bluff Thruse Fault; Southern Diamond Mountains, Eureka, and thite Pine Counties, Devada: U.S. Geol. Surv. Praf. Paper 424-C, pp. C113-C 115 .

Brer, D. A., 1963, Syncrogenic Sedimentation of Mississippian Age, Eureka Quadrangle, Nevada: Ph.D. Thesis, Stenford Univ., Palo Alto, Califurnia.

Brokaw, A. L., and Heidrick, T., 1966, Geologic Hap and Sections of the Giroux Wash Quadrangle, White Pine County, Hevada: U.S. Geol. Jurv. Geol. Quad. Map GQ-476.

Buckley, C. P., 1967, Structure and Stratigraphy of the Ringsley Mountains, Elko and thite Pine Counties, Fevada: M.S. Thesis, San Jose State College, San Jose, California.

Carlisle, D., Murphy, M. A., Nelson, C. A., and Winterer, E. L., 1957, Devonian Stratigraphy of Sulphur Springe and Pinon Ranges, Nevada: fmer. Assoc. Petroleum Geol. Bull., Vol. 41, pp. $2175-2191$.

Carlson, J. E., Laird, D. W., Peterson, J. A., Schilling, J. H., Silherman, M. L., and Stewart, J. H., 1975, Preliminary Map Showing Distribution and Isotopic Ages of Mesozo:c and Cenozoic Intrusive Rocks in Mevada: Ú.S. Geol. Surv. Open-File Report 75-499.

Chamberlin, T. L., 1975, Stratigraphy of the Ordovician Bly Sprirgs Dolomite in the Southeastern Great Basin, Utah and Nevada: Ph.D. Thesis, Univ. of Illinois, Urbans, Illinois.

Christensen, O. D., 1775, Metamorphism of the Manning Canyon and Chainman Pormations: Ph.D. Thes is, Stanford Univ., Palo Alto, California.

Collinson, J. W., 1966, Permian and Triassic Biostratigraphy of the Medicine Range, Elko County, Nevada: Ph.D. Thesis, Stanfcrd liniv., Palo Alto, California.

Collinson, J. K., 1958, Permian and Triassic Biostrat igraphy of the Medicine Range, Mortheastern Nevada: Earth Sci. Bull., Vol. 1, No. 4, Pp. 25-44. 
Coogan, A. H., 1952, Rarly Pennsylvanian Stratigraphy Biostratigraphy, and Sedimentation of the Bly Basin, Mevada: Ph.D. Thesis, Univ. of Illinois, Urbana, Illinois.

Couch, B. F., and Carpenter, J. A., 1943, Nevada's Metal and Mineral Production (1859-1940, inclusive): Nevada Univ. Bull., Vol. 37, No. 4 .

Dechert, C. P., 1963, Structure and Stratigraphy of the Northernmost Schell Creek Range, White Pine County, Nevada: M.S. Thesis, Univ. of Wshington, Seattle, Washington.

Dechert, C. P., 1967, Bedrock Geology of the Northern Schell Creek Range, White Pine County, Nevada: Ph.D., Thesis, Univ. of Washington, Seattle, Washington.

Desai, J. I., 1969, Petrography of the Raibab and Plympton Pormations (Pezmian), near Perguson Mountain, Blko County, Mevada: M.S. Thesis, Brigham Young Univ., Provo, Utah.

Dott, R. H., Jr., 1955, Pennsylvanian Stratigraphy of Elko and Northern Diamond Ranges, Northeastern Nevada: Amer. Assoc. Petroleun Geol. Bull., Vol. 39, No. 11, pp. 2211-2305.

Drewes, H., 1758, Structural Geology of the Southern Snake Range, Nevada: Geol. Soc. Amer. Bull., Vol. 69, No. 2, pp. 221-240.

Drewes, H., 1967, Geology of the Connors Pass Quadrangle, Schell Creek Range, Bast-Central Revada: U.S. Geol. Surv. Prof. Paper. 557 .

Drewes, H., and Palmer, A. R., 1957, Cambrian Rocks of Southern . Snake Bange, Nevada: Amer. Assoc. Petroleum Geol. Bull., Vol. 41, No. 1, pp. 104-120.

D'Silva, A. P., Floyd, M. A., and Haas, W. J., Jr., Multilaboratory Analytical Quality Control for the Hydrogeochemical and Stream Sediment Reconnaissance: Iowa State University, Ames Laboratory Ames, Iowa. A series of monthly reports sponsored by USDOF. Available from NTIS, Springfield, Virginia.

Dudley, W. W., 1967, Hydrogeology and Ground-Water Flow System of the Central Ruby Mountains, Fevada: Ph.D. Thesis, Univ. of Washington, Seattle, Washington.

Eakin, T. E., Price, D., and Harrill, J. R., 1976, Summary Appraisals of the Nation's Ground-Water Resources - Great Basin Region: Geol. Survey Prof. Paper 813-G, 37 pp.

Emmons, W. H., 1910, A Reconnaissance of Some Mining Camps in Elko, Lander, and Eureka Counties, Revada: U.S. Geol. Surv. Bull. 408. 
Erickson, R. L.: and Marsh, S. P., 1974, Paleozoic Tectonics in the Edna Mountain Quadrangle, Nevada: U.S. Geoi. Surv., J. Res., Vo1. 2, No. 3, pp. 331-337.

Evans, J. G., and Ketner, K. B., 1971, Geologic Yap of the Swales Mourtain Quadrangle and Part of the Adobe Sumit Quadrangle, Elka County, Mevada: U.S. Geo1. Surv., Misc. Geol. Inv., Map I-667.

Fenneman, N. M. , 1931, Physiography of Hestern Deited States: McGraw-Hill Bock Co., Inc., New York, N.Y., 534 pp.

Ferguson, H. G., and Muller, S. W., 1949, Structural Geology of the Hawthorne and Tonopah Quadrangles, Mevada: U.S. Geol. Surv., Prof. Paper 216.

Flynn, D. B., 1957, Ceology of a Part of the Dixie Plats Quadrangle, Elko County, Nevada: M.A. Thesis, U.C.L.A., Los Angeles, California.

Freyne, D. M., 1S73, Geology of the Ruby Lake SE T.5 Minute Quadrangle, White Pine County, Nevada: M.S. Thesis, California State Univ San Diego, California.

Fritz, W. H., 196), Structure and Stratigraphy of the Northern Egan Range, Thite Pine County, Nevada: Ph.D. Thesis, Univ, of Washington, Seattle, Washington.

Fritz, W. H., 196\&, Geologic Map and Sections of the Southern Cherry Creek and Northern Bgan Ranges, White Pine Cornty, Nevada: Navada Bur. Mines, Map 35.

Fultcn, J. A., and Smith, A. M., 1932, Nonmetallic Minerals in Bevada: Nevada Univ. Bull., Vol. 26, No. 7.

Garsi.̈e, L. J., and Schilling, J. H., 1977, Hells Drilled for Oil and Gas in Nerada Through 1976: Nevada Bur. Mir.es and Geol., Map 56.

Gilluly, J., and Masursiky, H. A., 1965, Geology of the Cortez Quadrangle, Nevada: U.S. Geol. Surv. Bul1. 1175.

Gordon, M., Je., and Duncan, H., 19E1, "Early Mississippian Faunas in Southwestern Elko County, Nevada;" in Short Papers on the Geologic and Hycrologic Sciences: U.S. Geol. S.rv., Prof. Paper 424-C, FF. C233-C234.

Granger, A. E., Bell,, M. M., Simmons, G. C., and Leə, F., 1957, Geology and Mineral Resources oi Elko County, Hevada: Nerada Bur. Mines and Geol., Buil. 54. 
Hague, A., 1883, Abstract of Report on Geology of the Eureka District, Nevada: U.S. Geol. Surv., 3rd Ann. Rept., pp. 227-290.

Hague, A., 1892, Geology of the Eureka District, Nevada: U.S. Geol. Surv,, Monog. 20.

Harlow, G. R., 1956, The Stratigraphy and Structure of the Spruce Mountain Area, Elko County, Mevada: M.S. Thesis, Univ. of Washington, Seattle, Washington.

Hess, F. L., ant Larsen, E. S., 1922, Contact-Metamorphic Tungsten Deposits of the Onited States: U.S. Geol. Surv. Bull. 725-D, Pp. 245-3C:9.

Hi11, J. M., 1916, The Mining Districts of the Destern United States: U.S. Geol. Surv. Bul1. 507.

Hintze, L. F., 1950, Ordovician Stratigraphy from Central Dtah to Central Devada: Ph.D. Thesis, Columbia Univ., New York, N.Y.

Hintze, L. F., 1951, Lower Ordovician Detailed Stratigraphic Sections for Western Utah: Utah Geol. Mineralog. Surv., Bull. 39.

Holmes, G. H., Jr.,. 1950, Investigation of the Cherry Creek Tungsten District, Thite Pine County, Nevada: U.S. Bur. Mines, Rept. Inv. 4631.

Hope, R. A., and Coats, R. P., 1976, Preliminary Geologic Map of Elko County, Revada: U.S. Geol. Surv., Open-File Report 76-779.

Hose, R. K., and Blake, M. C., Jr., 1976, Geology and Mineral Resources of thite Pine County, Revada: Nevada Bur. of Mines and Geol. Bull 85 .

Hose, R. K., and Repenning, C. A., 1959, Stratigraphy of Pennsylvanian Permian, and Lower Triassic Rocks of Confusion Range, WestCentral Otah: Amer. Assoc. Petrol. Geol. Bul1., Vol. 43, No. 9, pp. 2167-2196.

Howard, K. A., 1966, Structure of the Metamorphic Rocks of the Northern Ruby Mountains, Mevada: Ph.D. Thesis, Yale Univ., New Haven, Connecticut.

Jones, D. C., Wrucke, C. T., Holdeworth, G., and Suczek, C. A., 1978, Revised Ages of Chert in the Roberts Mountains Allochthon, Northern Nevada (Abs.): Geol. Soc. Amer., Abs. with Programs. 
Kellogg, H. E., 1963, Paleozoic Stratigraphy of the Southern

Egan Range, Nevada: Geol. Soc. Amer. Bull., Vol. 74, No. 6, pp. $685-708$.

Ketner, K. B., 1968, Ordovician Siliceous Sediments of the Cordilleran Geosyncline: Ph.D. Thesis, Univ. of Visconsin, Madison, Wisconsin.

Ketner, K. B., 1970, Geology and Mineral Potential of the Adobe Range, Elko Hilis, and Adjacent Areas, Elko County, Hevada: U.S. Seol. Surv., Prof. Paper 700-B, pp. B105-B108.

Ketner, K. B., 1973, Preliminary Geologic Map of Coal Mine Basin Quadrangle, Elko County, Nevada: U.S. Geol. Surv., Misc. Field Studies Map MF-528.

Ketner, K. B., 1974, Preliminary Geologic Map of the Blue Basin Quadrangle, Blko County, Hevada: U.S. Geol. Surv., Misc. Field Studies Map MF-559.

Ketner, K. E., 1977, "Late Paleozoic Orogeny and Sedimentation, Southern California, Nevada, Idaho, and Montana;" in Stewart, J. H., Stevens, C. H., and Fritsche, A. E., Eds., Paleozoic Paleogeography of the Western United States: Soc. Econ. Paleontologists and Mineralogists, Pacific Sec., Pacific Coast Paleogeography Symposium 1, pp. 363-369.

Ketner, K. B., and Smith, J. F., Jr., 1963, Geology of the Railroad Mining District, Elko County, Nevada: 'U.S. Geol. Surv., Bull. 1152-B.

Klepper, M. R., 1944, Starr Tungsten Mine and Vicinity, Harrison Pas8, Elko County: U.S. Geol. Surv., Strategic Minerals Inv. Prelim. Map.

Knorr, J. H., 1967, Permian Studies of Nevada (Clark, thite Pine, and Elko Counties): M.S. Thesis, Univ. of Iowa, Iowa City, Iowa.

Larson, E. R., and Riva, J. F., 1963, Preliminary Geologic Map of the Diamond Springs Quadrangle, Bevada: Nevada Bur. Mines, Map 20.

Lawson, A. C., 1906, The Upper Deposits of the Robinson Mining District, levada: Univ. of California, Berkeley, California, Dept. of Geology, Bul1. 4, pp. 287-357.

Lincoln, F. C., 1923, Mining Districts and Mineral Resources of Nevada: Nevada Newsletter Pub1. Co., Reno, Nevada.

Marcante1, J. B.: 1973, Opper Pennsylvanian and Lower Permian Sedimentation in Northeast Nevada: Ph.D. Thesis, Ohio State Univ., Columbus, Ohio. - 46 - 
McDowe11, F. W., 19;1, K-Ar Ages of Igneous Rocks from the Western United States: Isochron/West, No. 2, pp. 1-16.

McGuinness, C. L., 1963, The Role of Ground Dater in the National Water Situation: U.S. Geol. Survey, Water-Supply Paper 1800, $1121 \mathrm{pp}$.

McKee, E. H., Silberman, M. L., Marvin, R. E., and Obradovich, J. D., 1971 , A Summary of Radiometric Ages of Tertiary Volcanic Rocks in Nevada and Eastern California - Part I, Central Revada: Isochron/West. No. 2, pp. 21-42.

Merriam, C. W., 1940, Devonian Stratigraphy and Paleontology of the Roberts Mountains Region, Nevada: Geol. Soc. Amer., Special Paper 25.

Misch, P., 1960, "Regional Structural Reconnaissance in Central Northeastern Nevada and Some Adjacent Areas - Observations and Interprezations;" in Guidebook to the Geology of EastCentral Nevada: Intermountain Assoc. Petrol. Geol. and Eastern Nevada Geol. Soc., 11 th Ann. Field Conf., Salt Lake City, Utah, 1960, pp. 17-42.

Misch, P., and Hezzard, J. C., 1962, Stratigraphy and Metamorphism of Late Precambrian Rocks in Central Northeastern Nevada and Adjacent Utah: Amer. Assoc. Petrol. Geol. Bull., Vol. 46, No. 3, pp. 289-343.

Muffler, L. J. P., 1964, Geology of the Prenchie Creek Quadrangle North-Central Nevada: U.S. Geol. Surv. Bull. 1179.

Nelson, R.·B., :956, The Stratigraphy and Structure of the Region Surrounding Currie, Elko County, Nevada: M.S. Thesis, Univ. of Washingzon, Seattle, Washington.

NOAA, 1977, Records of Annual Precipitation: U.S. Department of Commerce, National Climatic Center, Asheville, North Carolina.

Nolan, T. B., 1935, The Gold Hill Mining District, Utah: U.S. Geol. Surv., Prof. Paper 177.

Nolan, T. B., 1943, The Basin and Range Province, Utah, Nevada, and California: U.S. Geol. Surv., Prof. Paper 197-D, Pp. D141-D196.

Nolan, T. B., 1962, The Eureka Mining District, Mevada: U.S. Geol. Surv., Prof. Paper 216.

Nolan, T. B., Merriam, C. W., and Williams, J. S., 1956, The Stratigraphic Section in the Vicinity of Eureka, Nevada: U.S. Geol Surv., Prof. Paper 276. 
Cesterling, W. A., 1962, Northwest Thrusting in Northeast Nevada: Wool Hil1s Thrust (Abs.): Geol. Soc. Amer., Special Paper 68.

O'Neil1, J. M., 19E8, Geology of the Southern Pilot Range, Elko County Merada, and Box Blder and Tooele Conties, Otah: M.S. Thesis, Uriv. of New Mexico, Albuquerque, New Mexico.

Pilger, K. H., Jr., 1972, Structural Geology of Part of the Morthern Toana Range, Elko County, Revada: M.S. Thesis, Univ. of Nebraska, Lincoln, Nebraska.

Poole, F. G., 1974, "Flysch Deposits of the Antler Foreland Basin, Western United States," in Dickinson, W. R., Ed., Tectonics and Sedimentation: Soc. Econ. Paleontologists and Minera1ogists, Special Pub. No, 22, pp. 58-82.

Poole, F. G., and Sandberg, C. A., 1975, Allochthonous Devonian Eugecsynclinal Rocks in the Toquima Range, Central Nevada: Geol. Soc. Amer., Abs, with Programs, Vol. i, No. 3, p. 361.

Poale, F. J., and Wardlaw, B. R., 1978, "Candelaria (Triassic) and Diablo (Permian: Formations in Southern Toquima Range, Central Nevada," in Howe11, D. G., and McDougall, R. A., Eds., Mesozoic Paleogeograpty of the Western United States: Soc. Econ. Paleontologists and Mineralogists, Pacific Sec., Pacific Coast Paleogeography, Symposium 2, pp. 1-16.

Price, V., and Jones, P., L, 1979, Training Manual for Nater and Sediment Geochemical Reconnaissance: SRL Doc ument DPST-79219, E. I. du Pont de Nemours \& Co., Savannah River Laboratory, Aiken, South Carolina. DOE-GJO Document No. GJBX-XX(79).*

Radtke, A. 3., 1976, Structural Controls and Genesis of Carlin-Type Gold Deposits in the Evolation of the Basin ard Range Province: Preprint with Program, 1976 Annual Mtg., Amer. Inst. Mining Metal1. Eng. (AIMME), Las Vegas, Bevada.

Raymond, R. W., 1373, Statistics of Mines and Hining in the States and Territories Hest of the Rocky Mountains for 1872: U.S. Treas. Dept., 5th Ann. Rept.

Regnier, J., 1960, Cenczoic Geology in the Vicinity of Carlin, Nevada: Geol. Soc. Amer. Bull., Vol. 71, No. B, pp. $1189-1210$.

Reid, J. A., 1904, Preliminary Report on the Building Stones of Revada: University of Nevada (Reno) Bul1., Vol. 1, No. 1.

Roberts, R. J., 196́4a, "Paleozoic Rocks," in Mineral and Mater Resources of Revada: Nevada Bur. Mines, Bul1. 55. 
Roberts, R. J., 1964b, Stratigraphy and Structure of the Antler Peak Quadrangle, Lander County, Nevada: U.S. Geol. Surv., Prof. Paper \$59-A.

Roberts, R. J., 1966, "Metallogenic Provinces and Mineral Belts in Nevada," in Papers Presented at AIME Pacific Southwest Mineral Industry Conference, Spark8, Nevada, May 5-7, 1965: Nevada 3ur. Mines, Rept. 13, Pt. A, pp. 47-52.

Roberts, R. J., and Lehner, R. E., 1955, Additional Data on the Age and Extent of the Roberts Mountain Thrust Fault, North-Central Nevada (Abs.): Geol. Soc. Amer. Bull., Vol. 66, pp. 2175-2191.

Roberts, R.' J., Jotz, P. E., Gilluly, J., and Ferguson, H. G., 1958, Paleczoic Rocks of Horth-Central Nevada: Amer. Assoc. Petroleum Geologists Bull., Vol. 42, pp. 2813-2857.

Roberts, R. J., Montgomery, R. M., and Lehner, R. F., 1967, Geology and Mineral Resources of Eureka County, Mevada: Nevada Bur. Mines, Bull. 64 .

Robinson, G. B., Jr., 1961, Stratigraphy and Leonardian Pusulinid Paleontolagy in Central Pequop Mountains, Elko County, Mevada: M.S. Thesis, Brigham Young Univ., Provo, Utah.

Ross, R. J., 1949, Stratigraphy and Trilobite Faunal Zones of the Garden City Formation, Northeastern Utah: Amer. J. Sci., Vol. 247, pp. 472-492.

Ross, R. J., 1951, Stratigraphy of the Garden City Formation in Northeastern Utah, and Its Trilobite Faunas: Peabody Mus. Nat. Hist., Bul1. 6, Yale Univ., New Haven, Connecticut.

Sanderson, D. D., 1972, Magnetic Minerals and Properties of the Melrose Stock (Early Cretaceous, Eastern Nevada): Ph.D. Thesis, Michigan State Univ., East Lansing, Michigan.

Sayyah, T. A., 1965, Geochronological Studies of the Kinsley Stock, Nevada, and Raft River Range, Utah: Ph.D. Thesis, Brigham Young Y Univ., Provo, Utah.

Schilling, J. H., 1965, Isotopic Age Determinations of Nevada Rocks: Nevada Bur. Mines, Rept. 10.

Schrader, F. C., 1931, Spruce Mountain District, Elko County, and Cherry Creek (Egan Canyon) District, White Pine County, Nevada: Univ. of Nevada (Reno) Bull., Vol. 25, No. 7.

Schrader, F. C., Stone, R. W., and Sanford, S., 1917, Useful Minerals of the United States: U.S. Geo. Surv. Bull. 624. 
Sharp, R. P., 1938, Pleistocene Glaciation in the Ruby-East Humboldt Range, Hortheastern Nevacia: J. Geomorph., Vol. 1, pp. 296-323.

Sharp, R. P., i939, The Miocene Humboldt Formation in Northeastern Nerada: Geol. Soc. Amer. Bull, Vol. 4i, No. 2, pp. 133-160.

Sharp, E. P., 1940, Geomorphology of the Ruby-East Humboldt Range, Nevada: Geol. Soc. Amer. Bull., Vol. 51, No. 3, pp. 337-371.

Sharp, R. P. 1942, Stratigraphy and Structure of the Southern Ruby Mountains, Merada: Geol. Soc. Amer. Bul1., Vol. 53, No. 5, pp. 647-690.

Srawe, D. R., Poole, F. G., and Heyl, A. V., 19:8, "Geologic Framework of the Cordilleran Region Traversed by Field Excursion $\mathrm{C}-1$ in Eastern Nevada and Western Utah;" in Shawe, D. R., Fd., Guicebook to Mineral Deposits of the Central Great Basin: Nevada Bur. Miaes and Geol., Rept. 32.

Sides, J. W., 1956, The Geology of the Central Bitte Mountains, White Pine County, Nevada: Ph.D. Thesis, Stanford Univ., Palo Alto Californie.

Silberling, N. I., 19ד3, "Geologic Events Durirg Permian-Triassic Time Along the Pacific Margin of the United States;" in Logan, A., and Hills, L. V., Eds., The Permian and Triassic Systems and Their Mutual Boundary: Canadian Soc. Petrol. Geol., Mem. 2, pp. 345-362.

Silberling;, N. J., and Roberts, R. J., 1962, Pre-Tertiary Stratigraphy and Structure of Morthwestern Hevada: Geol. Soc. Amer., Spec. Paper 72.

Silberman, M. L., and Nickee, E. H., 1973, R-Ar Ages of Tertiary Igneous Rocks and Hydrothermal Gold and Silver Deposits in Central and Hestern Nevada: Geol. Soc. Amer., Abstracts with Programs, Cordilleran Section.

Silitonga, P. H., 1974, Geology of Part of the Rittridge Springs Quadrangle, Blko County, Neveda: M.S. Thesis, Colorado School Mines, Golden, Colorado.

Slad $=$, M. L., 1961, Penrsylvanian and Permian Pusulinids of the Ferguson Mountain Area, Elko County, Revada: M.S. Thesis, Brighan Young Univ., Provo, Utah.

Smith, F. J., and Ketner, K. B., 1968, Devonian and Mississippian Rocks and the Date of the Roberts Mountain Thrust in the Carlin-Pinon Range Area, Mevada: U.S. Geol. Sirv. Bull. 1252-I. 
Smith, J. F., Jr., and Ketner, K. B., 1975, Stratigraphy of Paleozoic Rocks in the Carlin-Pinon Range Area, Mevada: U.S. Geol. Surv., Prof. Paper 867-A, Pp. Al-A87.

Snelson, S., 1955, The Geology of the Southern Pequop Mountains in Elko County, Northeastern Nevada: M.S.. Thesis, Univ. of Washington, Seattle, Washington.

Snelson, S. 1957, The Geology of the Northern Ruby Mountains and the East Humboldt Range, Elko County, Northeastern Mevada: $\mathrm{Ph} . \mathrm{D}$. Thesis, Univ. of Washington, Seattle, Washington.

Snow, G. G., 1964, Mineralogy and Geology of the Dolly Varden Mountains, Elko County, Nevada: Ph.D. Thesis, Univ. of Utah, Salt Lake City, Utah.

Spencer, A. C., 1917, The Geology and Ore Deposits of Ely, Revada: U.S. Geol, Surv., Prof. Paper 96.

SRL-138, Savannah River Laboratory Quarterly and Semiannual Reports, Hydrogeochemical and Stream Sediment Reconnaissance, National Uranium Resource Evaluation Program: E. I. du Pont de Nemcurs \& Co., Savannah River Laboratory, Aiken, S.C.

\begin{tabular}{|c|c|c|c|}
\hline No. & Period & SRL Doc. No. & Doc. No.* \\
\hline 1 & January-March 1975 & DPST $-75-138-1$ & GJRX $-5(76)$ \\
\hline 2 & April-June 1975 & DPST $-75-138-2$ & $\mathrm{GJBX}-6(76)$ \\
\hline 3 & July-September 1975 & DPST $-75-138-3$ & $G J B X-7(76)$ \\
\hline 4 & October-December 1975 & DPST $-75-138-4$ & GJBX-8(76) \\
\hline 5 & January-March 1976 & DPST $-76-138-1$ & GJBX-17(76) \\
\hline 6 & April-June 1976 & DPST $-76-138-2$ & GJBX-27(76) \\
\hline 7 & July-September 1976 & DPST $-76-138-3$ & $G J B X-63(76)$ \\
\hline 8 & October-December 1976 & DPST $-76-138-4$ & GJBX-6(77) \\
\hline 9 & Jaruary-March 1977 & DPST-77-138-1 & $G J B X-35(77)$ \\
\hline 10 & April-June 1977 & DPST $-77-138-2$ & GJBX-55(77) \\
\hline 11 & Juiy-September 1977 & DPST $-77-138-3$ & $G J B X-90(77)$ \\
\hline 12 & October-December 1977 & DPST $-77-138-4$ & GJBX-37(78) \\
\hline 13 & January-March 1978 & DPST $-78-138-1$ & GJBX-66(78) \\
\hline 14 & Afril-September 1978 & DPST $-78-138-2$ & $G J B X-13(79)$ \\
\hline 15 & October 1978-March 1979 & DPST $-79-138-1$ & GJBX-86:79) \\
\hline 16 & April-September 1979 & DPST $-79-138-2$ & GJBX-160(79) \\
\hline 17 & Oetober 1979-March 1980 & DPST $-80-138-1$ & (in process) \\
\hline
\end{tabular}


SF-146, SRL-NJUE Data Reports, E. I. du Pont de lNemours \& Co., Savannah River Laboratory, Aiken, S. C.

\begin{tabular}{|c|c|c|c|}
\hline No. & $\begin{array}{l}\text { NTMS } 1^{\circ} \times 2^{\circ} \\
\text { Quadrangle }\end{array}$ & SRL Doc. No. & $\begin{array}{l}\text { DOE-GJO } \\
\text { Doc . No * * }\end{array}$ \\
\hline 1 & Winston-Salem & DPST-77-146-1 & $G J B X-66(77)$ \\
\hline 2 & Spartanburg & DPST $-77-146-2$ & GJEX-09(78) \\
\hline 3 & Char lotte & DPST-78-146-1 & GJBX-40(78) \\
\hline 4 & Greenrille & DPST-78-146-2 & GJBX-47(78) \\
\hline 5 & Winston-Salem $\dagger$ & DPST $-78-146-3$ & GJBK-58(78) \\
\hline 6 & Greensbora & DPST-78-146-4 & GJBX-74(78) \\
\hline$T$ & Knoxville & DPST $-78-146-5$ & GJBD-75(79) \\
\hline 8 & Scranton & DPST $-78-146-6$ & GJBX-02(79) \\
\hline 9 & Athens: & DPST-78-146-7 & GJBX-20(79) \\
\hline 10 & Harrisburg & DPST-79-146-1 & GJBX-31(79) \\
\hline 11 & Portland & DPST-79-146-2 & BJBX-28(79) \\
\hline 12 & Slens Falls & DPST $-79-146-3$ & $6 J \mathrm{BX}-44(79)$ \\
\hline 13 & Augusta & DPST-79-146-4 & GJBX-45(79) \\
\hline 14 & Dyersturg & DPST-79-146-5 & EJBX $-58(79)$ \\
\hline 15 & Poplar Bluff & DPST-79-146-6 & GJBX-63(79) \\
\hline 16 & Fartford & DPST-79-146-7 & GJ3X-94(79) \\
\hline 17 & Villians por: & DPST $-79-146-8$ & GJBX-152(79) \\
\hline 18 & Newark & DPST-79-146-9 & (in process) \\
\hline 19 & Albany & DPST $-79-146-10$ & GJEX-140(79) \\
\hline 20 & $A=l$ ant $a$ & DPST-79-146-11 & GIBX-129(79) \\
\hline 21 & Delta, Richfield $\dagger+\dagger$ & DPST $-79-146-12$ & $G=B X-161(79)$ \\
\hline 22 & Walker Lake & DPST $-79-146-13$ & GJBX-i07(80) \\
\hline 23 & McDermitt, Walls ${ }^{\dagger} \dagger \dagger$ & DPST-79-146-14 & GJBK-117(80) \\
\hline 24 & Reno & DPST $-79-146-15$ & $G J B X-108) 80)$ \\
\hline 25 & Death Valley & DPST-79-146-16 & in process) \\
\hline 26 & Flagstaff & DPST-79-146-17 & (in process) \\
\hline 27 & Marble Canyon & DPST-79-146-18 & (in process) \\
\hline 28 & Grand Canyon & DPST-79-146-19 & (in process) \\
\hline 29 & Pocate 110 & DPST $-79-146-20$ & (in process) \\
\hline 30 & Mesa & DPST-80-146-1S & GJBX $-81(80)$ \\
\hline 31 & Salton Sea & DPST-80-146-2S & G.JBX-113(80) \\
\hline 32 & Ritzville & DPST $-80-146-3$ & (in process) \\
\hline 33 & Elko & DPST-80-146-4 & (this report) \\
\hline 34 & Challis & DPST-80-146-5 & $G J B A-91(80)$ \\
\hline
\end{tabular}

1 Sedinent only.

$\dagger+$ Ground water only.

t† SRL Enalyses of samples collected by Lawreaze Livermore Laboratory. 
Steele, G., 1959; Stratigraphic Interpretation of the Pennsylvanian-Permian Systems of the Eastern Great Basin: Ph.D. Thesis, Univ.: of Washington, Seattle, Washington.

Steele, G., 1960, "Pennsylvanian-Permian Stratigraphy of East-Central Nevada and Adjacent Utah," in Guidebook to the Geology of BastCentral Nevaca: Intermountain Assoc. Petrol. Geol, and Eastern Nevada Geol. Soc. 11 th Ann. Field Conf., Salt Lake City, Utah.

Steininger, R., 1966, Geology of the Ringsley Mining District, Elko County, Nevada: M.S. Thesis, Brigham Young Univ., Provo, Utah.

Stevens, C. H., 1963, Paleoecology and Stratigraphy of Pre-Kiabab Permian Rocks in the Ely Basin, Nevada and Dtah: Ph.D.

Thesis, Univ. of Southern California, Los Angeles, California.

Thorman, C. H., 1962, Structure and Stratigraphy of the Wood Hills and a Portion of the Northern Pequop Mountains, Elko County, Nevada: Ph.D. Thesis, Univ. of Washington, Seattle, Washington.

U.S. Bureau of Census, Census of Population, 1970, and Census of Agriculture, 1970, Washington, D. C. Available from Superintendent of Documents, NTIS, Springfield, Virginia.

Van Barneve1d, N. N., 1916, Report on the Properties of the Revada Bunker Hill Mining Co.: A Company Report.

Vanderburg, W. D., 1936, Reconnaissance of Mining Districts in Eureka County, Nevada: U.S. Bur. Mines, Inf. Circ. 7022.

Walcott, C. D. 1908, Cambrian Sections of the Cordilleran Area: Smithonian Misc. Coll., Vol. 53.

Webb, G. W., 1960, Middle Ordovician Stratigraphy in Eastern Mevada and Nestern Utah: Ph.D. Thesis, Columbia Univ., New York, N.Y.

Wheeler, H. E., and Lemmon, D. M., 1939, Cambrian Pormations of the Eureka and Pioche Districts, Mevada: Univ. of Nevada (Reno), Vol. 33, No. 3, and Nev. Bur. Mines Bul1. 31.

White, A. F., 1871, Third Biennial Report of the State Mineralogist of Nevada for the Years 1869 and 1870: Carson City, Nevada.

Whitebread, D., 1969, Geologic Map of the Wheeler Peak and Garrison Quadrangles, Nevada and Utah: U.S. Geol. Surv., Misc. Gaol., Inv. Map I-578. 
Whitehil_, H. R., 1875, Biennial Report of the State Mineralogist of Mevada for the Years 1873 and 1874: Carson City, Nevada.

Willden, R., Thomas, H. H., and Stern, T..W., 1965, "Oligocene or Younger Thrust Faulting in the Ruby Mountains, Northeastern Nevada;" in Abstracts for 1965: Geol. So:. Amer., Spec. Papers 87, p. 239.

Willden, R., and Kistler, R. W., 1967, Ordovicien Tectonism in the Ruby Mountains, Rlko County, Revada: U.S. Geol. Surv., Prof. Paper 575-D, Pp. D64-D75.

Willden, R., and Kistler, R. W., 1969, Geologic Lap of the Jiggs Quadrangle, Elko County, Revada: U.S. Geol. Surv., Geol. Quad. Map GQ-859.

Winchester, D. E., 1923, Oil Shale of the Rocky Hountain Region: U.S. Seol. Surv. Bull. 729.

Winfrey, W. M., Jr., 1958, Stratigraphy, Correlation, and 0il Potencial of the Sheep Pass Formation, Bast-Central Nevada; Arer. Assoc. Petrol. Geol., Rocky Mountain SEc., Geol. Rec., pp. 7:-82.

Woodward, I. A., 1964, Structural Geology of Central Morthern Bgan Range, Nevada: Amer. Assoc. Petrol. Geol. Bull., Vol. 48, No. 1 , pp. 22-39.

Young, J. C., 1960: "Structure and Stratigraphy ir. North-Central Schell Creek: Range;" in Guidebook to the Geology of EastCentral Mevade: Intermountain Assoc. Petrol. Geol. and Eastern Nevacia Geol. Soc., 11th Ann. Field Cor.f., Salt Lake City, Otah.

* DOE-GJO reports are arailable on microfiche from the Grand Junction office, DOE, for $\$ 5.00$. Prepaid orders shou- 1 be sent to: Bendix Fielf Engizeering Corporation, Technical lijrary, P.0. Box 1569, Grand Junction, CO 91501. Checks or mor:ey orders should be made out to Bendix Field Engineering Corpcration, the operstions contractor for DOE's Grand Junction Office. 


\section{Immed fate :}

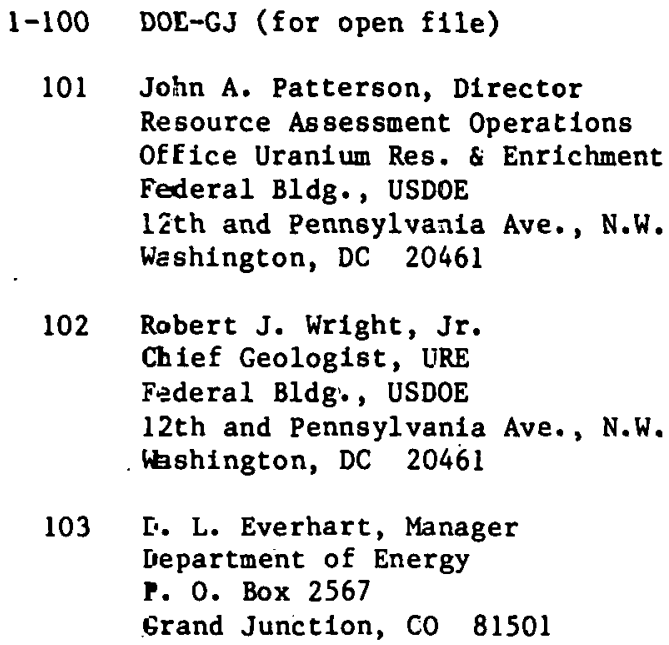

103 [.. L. Everhart, Manager

Department of Energy

P. 0. Box 2567

Grand Junction, CO 81501

\section{Delayed (after DOE-GJO release)}

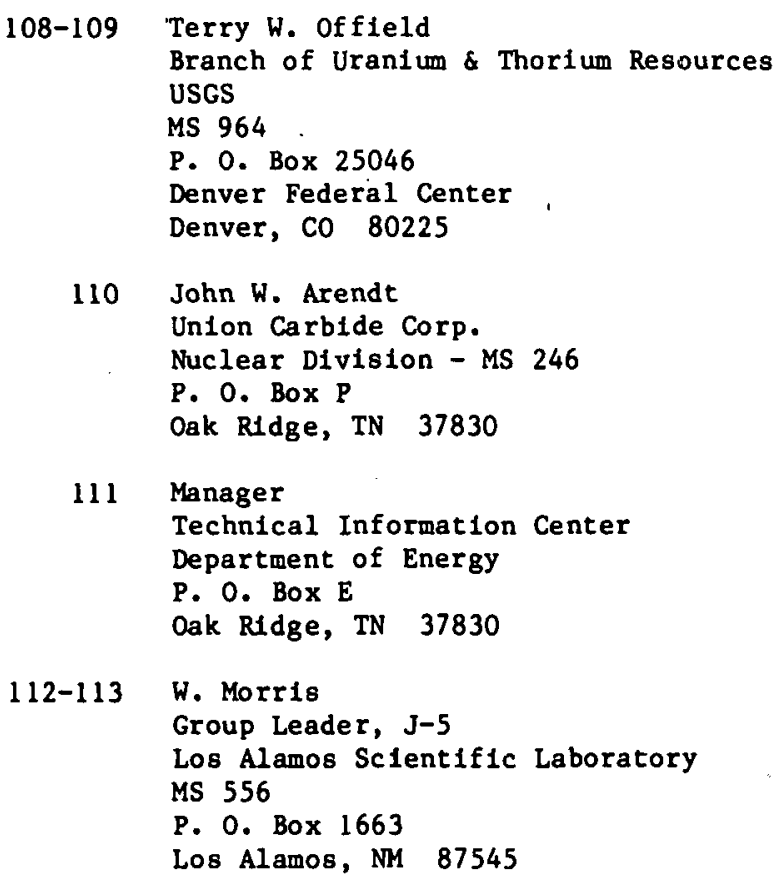

104 Carl H. Roach NURE Projec: Manager Department of Energy P. 0. Box 2567 Grand Junction, CO 81501

105 David H. Dehlem, Project of flicer NURE Project office Department of Energy P. 0. Box 2567 Grand Junction, CO 81501

106-107 Donald E. Ifvingston, Manager Geochemical Department, DADD Bendix Fitild Eagineering Corp. P. 0. Box 1569 Grand Junction, CO 81501

114 Dr. Ken Folt $j i$, Ass't Director USDA - Forest Service Watershed Unit 633 W. Wisconsin Ave. Milwaukee, WI 55202

115 Mr. Frank McElwain U. S. Forest Service 324 25th St. Ogden, UT 84401

116 State D-rector Bureau of Land Management Arizona State office 2400 Valley Bank Center Phoentx, AZ 85073

Att'n: Div, of Resources Ma1l stop 930

117 Charles M. Johnson Water and Mineral Consultants, Inc. 1255 0ak Hills Dr. Colorado Springs, Co 80919

118-120 DOE-SE

121 TIS Record Copy

122-126. TIS File

127-170 SRL-NIRE Files 